\section{OPEN ACCESS}

Edited by:

Lee Mark Wetzler

Boston University School of Medicine, USA

Reviewed by:

Olivier Garraud,

Institut National de la Transfusion

Sanguine, France

Michael Kogut,

U.S. Department of

Agriculture - Agricultural

Research Service (USDA-ARS), USA

Narinder K. Mehra,

All India Institute of Medical Sciences,

India

${ }^{*}$ Correspondence:

Paulo Rodrigues-Santos

paulo.santos@fmed.uc.pt

† Jeane Eliete Laguila Visentainer and Paulo Rodrigues-Santos contributed equally and should be considered as senior authors.

Specialty section:

This article was submitted to Microbial Immunology,

a section of the journal

Frontiers in Immunology

Received: 25 June 2015

Accepted: 23 December 2015

Published: 12 January 2016

Citation:

Mazini PS, Alves HV, Reis PG, Lopes AP, Sell AM, Santos-Rosa M,

Visentainer JEL and Rodrigues-

Santos P (2016) Gene Association with Leprosy: A Review of Published

Data.

Front. Immunol. 6:658. doi: 10.3389/fimmu.2015.00658

\title{
Gene Association with Leprosy: A Review of Published Data
}

\author{
Priscila Saamara Mazini'1,2, Hugo Vicentin Alves², Pâmela Guimarães Reis², \\ Ana Paula Lopes ${ }^{2}$, Ana Maria Sell2, Manuel Santos-Rosa ${ }^{1,3}$, \\ Jeane Eliete Laguila Visentainer ${ }^{2 \dagger}$ and Paulo Rodrigues-Santos ${ }^{1,3 * \dagger}$
}

${ }^{1}$ Faculty of Medicine, Immunology Institute, University of Coimbra, Coimbra, Portugal, ${ }^{2}$ Immunogenetics Laboratory, Department of Basic Health Sciences, Maringá State University, Maringá, Paraná, Brazil, ${ }^{3}$ Immunology and Oncology Laboratory, Center for Neurosciences and Cell Biology, University of Coimbra, Coimbra, Portugal

Leprosy is a chronic infectious disease caused by an obligate intracellular bacterium known as Mycobacterium leprae. Exposure to the bacillus is necessary, but this alone does not mean an individual will develop clinical symptoms of the disease. In recent years, several genes have been associated with leprosy and the innate immune response pathways converge on the main hypothesis that genes are involved in the susceptibility for the disease in two distinct steps: for leprosy per se and in the development of the different clinical forms. These genes participate in the sensing, main metabolic pathway of immune response activation and, subsequently, on the evolution of the disease into its clinical forms. The aim of this review is to highlight the role of innate immune response in the context of leprosy, stressing their participation in the signaling and targeting processes in response to bacillus infection and on the evolution to the clinical forms of the disease.

Keywords: leprosy, innate immunity, immune response genes, Mycobacterium leprae

\section{INTRODUCTION}

The clinical manifestations of leprosy depend on the interaction between the Mycobacterium leprae (M. leprae) and the individual's immune system $(1,2)$. The indeterminate form of the disease usually appears at the beginning and could evolve into a cure or to any of the clinical forms mentioned below. Depending on the immune profile of the host against infection, the disease may present within a spectrum of clinical manifestations that vary from a localized form [tuberculoid-tuberculoid (TT)] to a disseminated form [lepromatous leprosy (LL)] or one of three intermediate forms (borderlinetuberculoid; borderline-borderline; borderline-lepromatous) (3).

Although the phenotype of susceptibility to infection by M. leprae is complex and influenced by factors of the host and the parasite, and also by environmental conditions, some studies have suggested the human genetic factors as important on the acquisition of leprosy and the clinical course of disease $(4,5)$.

\section{PATHOGEN VS. HOST}

Although considerable attention has been focused on the development of the adaptive cellular immune response during the course of infection, recent investigations of the mechanisms and modulation of innate immunity support the idea that after the indeterminate leprosy, immunoregulatory 
events should occur, which determine the spectrum of disease. The innate immune response, which is the first line of defense against $M$. leprae, is considered a crucial factor in the development of a response against the bacillus as it has essential effector components to combat the pathogen and is able to direct adaptive immunity (6). Most individuals exposed to M. leprae do not develop the disease, which may be explained, at least in part, by innate resistance provided by the individual's genetic background (1), as demonstrated by recent clinical and epidemiological evidence (7). This demonstrates the need of studies investigating genetic markers associated with the disease. The spectrum of leprosy can be represented in the following model (Figure 1) (8).

An individual when exposed to $M$. leprae can develop leprosy per se under the influence of environmental and genetic factors that act on the immune response genes determining efficiency in response to infection. If a person develops the disease, it can be taken spontaneously, with good immune response induced by genetic factors or develop the spectrum of leprosy developing any clinical signs: TT, BT, BB, BL, and LL. In the paucibacillary (PB) polo (tuberculoid form, TT), activation of Th1 response occurs from $\mathrm{TCD}^{+}$-activating macrophages to release inflammatory cytokines and proinflammatory that lead to cell-mediated immunity. While multibacillary (MB) pole is driven by Th2 response, which produces anti-inflammatory cytokines, thereby inhibiting macrophage microbicidal function of extending the disease to a pole with high bacterial load. When an individual is exposed to $M$. leprae, he can develop leprosy per se by the influence of environmental and genetic factors that act on genes from the immune system, which determines the response efficiency to the infection. If a person develops the disease, it can be taken spontaneously, with good immune response induced by genetic factors, or develop the spectrum of leprosy developing clinical signs: TT, BT, BB, BL, and LL. In the PB polo (tuberculoid form,
TT), activation of Th1 response occurs from TCD4+-activating macrophages releasing inflammatory and proinflammatory cytokines that lead to cell-mediated immunity. When MB pole is driven by Th2 response, the production of anti-inflammatory cytokines will inhibit macrophage microbicidal function, extending the disease to a pole with high bacterial load.

\section{RESPONSE INNATE IMMUNE IN LEPROSY}

As shown in Figure 1, cell-mediated immunity, phagocytes such as macrophages, for example, are activated and have a relevant role in innate immunity. In these cells, as well as neutrophils, natural killer (NK) cells, and some lymphocytes, are present receptors/ sensors responsible for the activation of innate immunity, such as TLRs, VDR, NRAMP1, MRC1, NLRs, MBL, PARK2/PACRG, $M I C, K I R$, cytokines, and CD14. Macrophages are phagocytic cells that internalize microorganisms so that they are processed and presented to T cells (TCR) by the MHC molecules, as well as generate inflammatory responses reactions with the release of oxygen and nitrogen species (oxidative bust) and cytokines that can activate other cells of the immune system. T cells, in turn, release IFN- $\gamma$ that may activate other immune system cells, which are capable of eliminating infected cells. Still, the NRAMP1 gene is encoded inside the macrophages, lysosome membrane proteins that assist in the process of phagocytosis, acting on ion transport.

The immune cells have cell surface receptors that can promote a downstream signaling. Among the surface receptors of innate response, there are TLRs, which sense microorganisms and cell activation; VDR, which together with the TLR2 participates in the activation of the vitamin D-mediated antimicrobial pathway, where the vitamin $\mathrm{D}$ receptor (VDR) induces the production of antimicrobial peptides, such as cathelicidin; MRC with the TLR and NOD-2 modulate the autophagy and are involved in

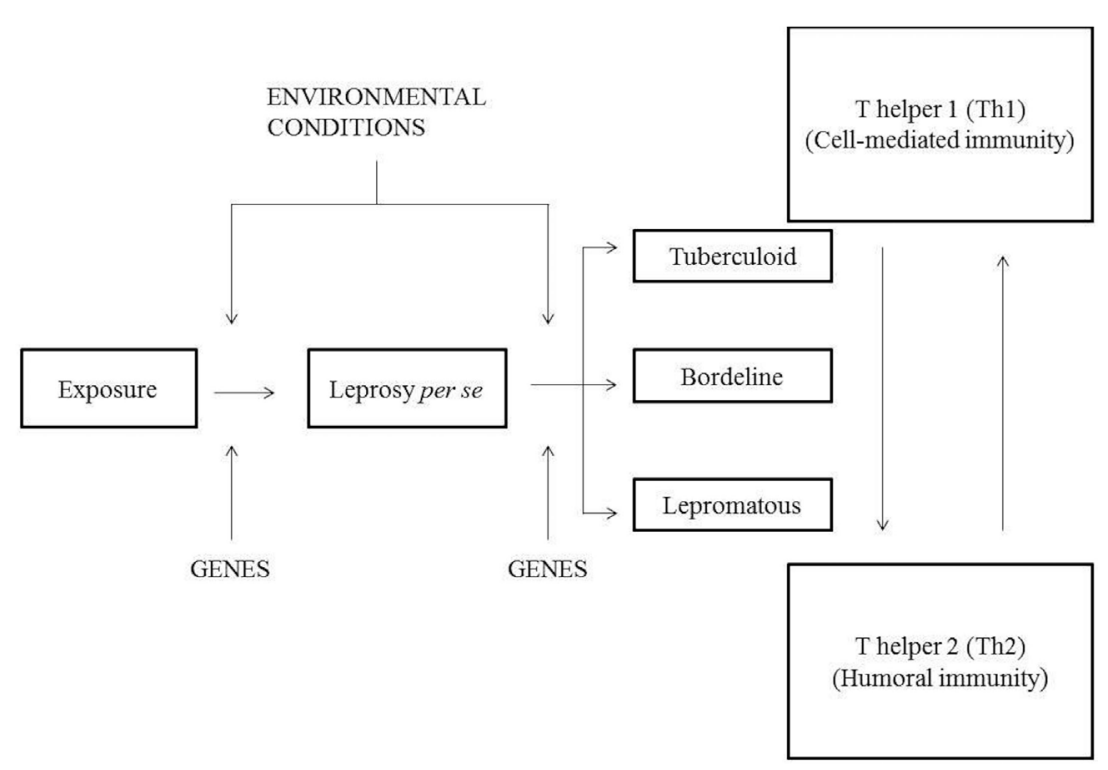

FIGURE 1 | Model of the leprosy spectrum according to Prevedello and Mira (8). 
host-pathogen interactions; They are important in the sensing of mycobacterial peptides; MIC, which are proteins that are induced into a state of cellular stress, and can be recognized by the NKG2D receptor on the surface of T $\gamma \delta$ lymphocytes, $\mathrm{CD} 8^{+} \alpha \beta$ T lymphocytes, and NK cells that contribute to defend the body against infections. Other TLRs receptors are expressed in endosome compartments, and there are still receptors present in the cytoplasm as NOD2 and RIG1, acting as cytosolic sensors in the presence of bacteria and viruses, which might have escaped the intracellular internalization. These receptors recognize peptides while releasing cytokines and activate the complement inflammatory system and therefore cytokines for adequate inflammatory response. The PARK2 acts in the coding process of E3 ubiquitinase necessary signaling cascade in certain cellular processes, such as NOD2, requiring E3 ubiquitin in NF-kB activation process. NK cells recognize MIC expressed in infected cells by NKG2D receptor. These cells also express killer cell immunoglobulin-like receptor (KIR) molecules for activation and inhibition, as well as MHC class I and II, that can recognize peptides and to activate T lymphocyte. Markers characteristic of these cells (NK) are CD56 (Figure 2).

\section{Toll-Like Receptors}

Pattern recognition receptors (PRRs), stand out in the innate immune response, such as Toll-like receptors are present on the cell surface (TLR1, TLR2, TLR4, TLR5, and TLR6), sensing microbial components such with lipids, lipoproteins, and proteins and also in the cytoplasm (TLR3, TLR7, TLR8, and TLR9) sensing microbial and viral species of nucleic acids. The receptors TLR1/2 are the first to act by promoting cell activation in the presence of M. leprae $(9,10)$. TLR1 recognize lipoproteins present in bacillus and promote the differentiation of monocytes in macrophages with the release of cytokines, such as IFN- $\gamma$ and IL-6, and also affect the maturation of dendritic cells $\mathrm{CD} \mathrm{b}^{+}$, which can activate other effector cells of the immune system, such as T cells, promoting an anti-microbicide activity (11-14) (Figure 3).

Some TLR genes indicate influence of the development of mycobacterial diseases because they are able to detect different molecules in the bacillus Mycobacterium sp. such as lipomannan, lipoarabinomannan, phosphatidylinositol mannoside, laminin, LPS, and lipoprotein glycolipids. Once in contact with the TLR receptor, a signaling cascade is initiated within the host cell. Therefore, alterations in these genes may confer susceptibility/ resistance to leprosy development.

TLR1 N248S polymorphism was studied in a population of Bangladesh. The homozygous genotype SS was associated with leprosy, but as a protective factor to the development of ENLtype reactions, and the heterozygous genotype $\mathrm{SN}$ was associated with protection against leprosy (15). In populations of Brazil, case-control and family studies have been performed with 3,162 individuals showing an association between TLR1 248S and leprosy; corroborating the finding that $248 \mathrm{~S}$ is a susceptibility factor for leprosy (16). A case-control study also investigated the TLR1-I602S SNP in three distinct populations: New Delhi, Kolkata, and Turkey; the authors reached the same conclusions thereby demonstrating consistency in the data obtained (17).
SNPs in other genes of the TLR family have also been investigated and their mechanisms of action have been evaluated. One study reported the analysis of the TLR1 gene (N602S) and the TLR6 gene $(\mathrm{G} 1083 \mathrm{C})$, both of which were associated with increased IFN- $\gamma$ levels. The TLR6 (G1083C, C745T) was associated with increased IL-2 levels, whereas TLR1 (A1188T) was associated with elevated IFN- $\gamma$ and IL-2 levels (18). Three polymorphisms in TLR2 (597C > T, 1350T > C, and a microsatellite marker) were analyzed in 431 Ethiopian patients with leprosy and 187 control subjects. The microsatellite and the $597 \mathrm{C}>\mathrm{T}$ polymorphisms both influenced susceptibility to reversal reaction (19). The influence of GT microsatellite on the expression of TLR2 was measured in 88 leprosy patients, 95 household contacts, and 96 healthy controls. The allele/genotype of TLR2 microsatellite that includes longer GT repeats was associated with low TLR2 mRNA expression and high IL-10 production, while that the shorter GT repeats were associated with high TLR2 mRNA expression and low IL-10 production. High IL-10 producing allele of TLR2 microsatellite might predispose household contacts to leprosy (20). One study on the TLR4 gene (896GA, 1196CT) in an African population showed a protective effect of 896GA and 1196TT against the development of the leprosy (21). Additionally, this study suggested that polymorphisms in the TLR2 gene increase the risk of a patient developing reversal reactions; however, this polymorphism was not considered a risk factor for the development of leprosy per se. These reports on different ethnic groups reinforce the idea that Toll-like gene receptors participate in the outcome of leprosy.

\section{Vitamin D Receptor}

TLR2 participates in the activation of the vitamin D-mediated antimicrobial pathway, where the VDR induces the production of antimicrobial peptides, such as cathelicidin. Polymorphisms in the VDR gene can destabilize and/or modify mRNA activity of the VDR, resulting in susceptibility to intracellular pathogens (22). This vitamin-receptor interaction leads to the suppression of several genes, such as interleukin-12 (IL12), colony-stimulating factor 2 (CSF2) coding granulocyte-macrophage colony-stimulating factor (GM-CSF), interferon-gamma (IFNG), and HLA-DRB1, inhibiting the production of cytokines and immunoglobulins, and lymphocyte proliferation (22-24).

Various polymorphisms in the VDR gene are being investigated for interfering in the mRNA activity and transcription. Polymorphisms located near the 3'UTR of the VDR gene (BsmI, ApaI, and TaqI) are related to the stability/transcriptional activity of VDR mRNA, while a polymorphism located in the translation initiation codon, FokI, gives rise to a three amino acid difference in the VDR length that affects protein function (25). TaqI polymorphism in the VDR gene can occur by a substitution of a $\mathrm{C}$ nucleotide for $\mathrm{T}$, with the loss of a TaqI restriction site in the gene, resulting in "T" (wild) and " $\mathrm{t}$ " (normal) alleles. A study of the population of Mexico associated the TT genotype in the $V D R$ gene to the lepromatous form of the disease (26), and also in the population of Calcutta, the $t t$ genotype was associated with Tuberculoid form leprosy, and the TT genotype was associated with Lepromatous form. Heterozygotes with the Tt genotype were 

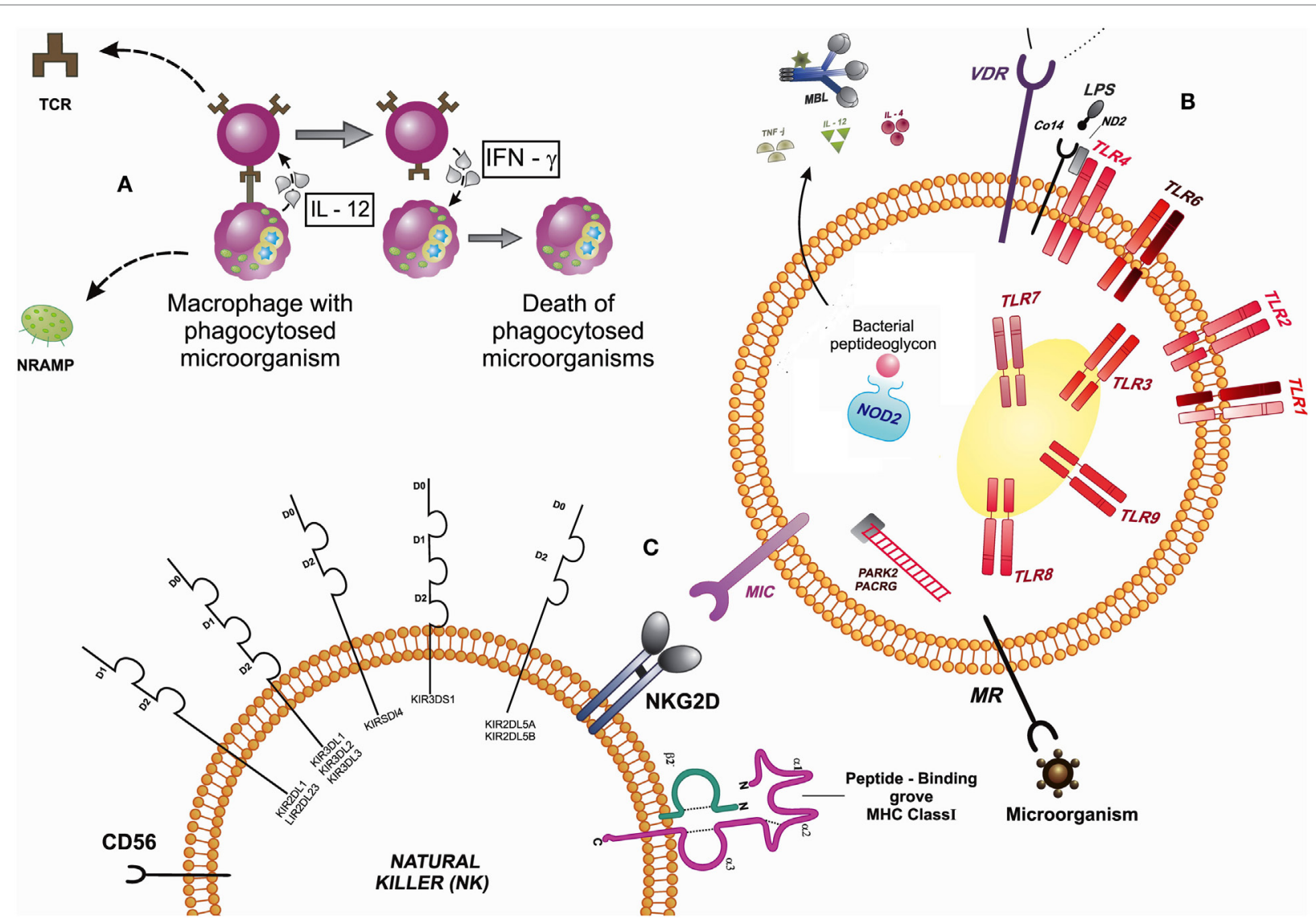

FIGURE 2 | Signaling between cells that participate in the innate immune response by expressing receptors that interact in the presence of a microorganism. (A) Macrophages are phagocytic cells that internalize microorganisms and presented to T cells (TCR). T cells, in turn, release IFN- $\gamma$ that may activate other immune system cells. The NRAMP1 gene is encoded inside the macrophages, lysosomal membrane proteins that assist in the process of phagocytosis, acting on ion transport. (B) The immune cells have cell surface receptors that can promote a downstream signaling: TLRs, VDR, MRC, and NOD-2 (modulate the autophagy). MIC, which are proteins that are induced into a state of cellular stress, can be recognized by the NKG2D receptor on the surface of T $\gamma \delta$ lymphocytes, $\mathrm{CD}^{+} \alpha \beta$ T lymphocytes, and natural killer cells (NK) that contribute to defend the body against infections. The PARK2 acts in the coding process of E3 ubiquitinase necessary signaling cascade in certain cellular processes, such as NOD2, requiring E3 ubiquitin in NF- $\mathrm{KB}$ activation process. (C) NK cells recognize MIC expressed in infected cells by NKG2D receptor. Abbreviations: TLR, toll-like receptors; MRC, mannose receptor of the C-type lectin; NOD2, nucleotide-binding oligomerization domain 2 protein, human; MBL, mannose-binding lectin; PACRG/PARK2, PACRG protein, human/PARK2-coregulated protein, human; MIC, major histocompatibility complex class I chain-related genes; KIR, killer cell immunoglobulin-like receptors; IL, interleukins; TNF, tumor necrosis factor; IFN, interferons; MHC, major histocompatibility complex; NKG2D, killer cell lectin-like receptor subfamily K; protein; NRAMP, natural resistance-associated macrophage protein; TCR, T-cell receptor; MR, mannose receptor; VDR, vitamin D receptor; LPS, lipopolysaccharide; MD2, myeloid differentiation protein-2, human.

found associated with protection against both leprosy types (23). Although a study of the TaqI polymorphism of the VDR gene in the population of Minas Gerais, Brazil, did not find significant differences, there was a higher frequency of the " $\mathrm{t}$ " allele in $\mathrm{MB}$ compared to $\mathrm{PB}$ patients and control individuals, suggesting the participation of this allele in developing the most severe form of the disease. In this study, a positive association was also observed between the $t t$ genotype and a negative Mitsuda test in patients with leprosy (22). In the population of Malawi, homozygotes with the $t$ genotype with a silent $\mathrm{T}>\mathrm{C}$ change in codon 352 of the VDR gene are susceptible to the disease (27). These different results can be the consequence of the diverse allele and genotype frequencies among populations.

\section{Natural Resistance-Associated Macrophage Protein 1 Gene}

The NRAMP1 gene, located in the chromosome $2 \mathrm{q} 35$ region, has been reported as one factor responsible for the resistance of mice to intracellular pathogens (28). In human cells, it is expressed in macrophages and encodes a protein found in lysosomal membranes that, in the process of phagocytosis, is recruited for phagosome membranes containing pathogens, where it acts as a transporter of iron and other divalent ions. Iron is essential for biological functions, both for host immune defense and mycobacterial growth.

In a study performed in an endemic region of Brazil, there were no significant differences in the allelic and genotypic 


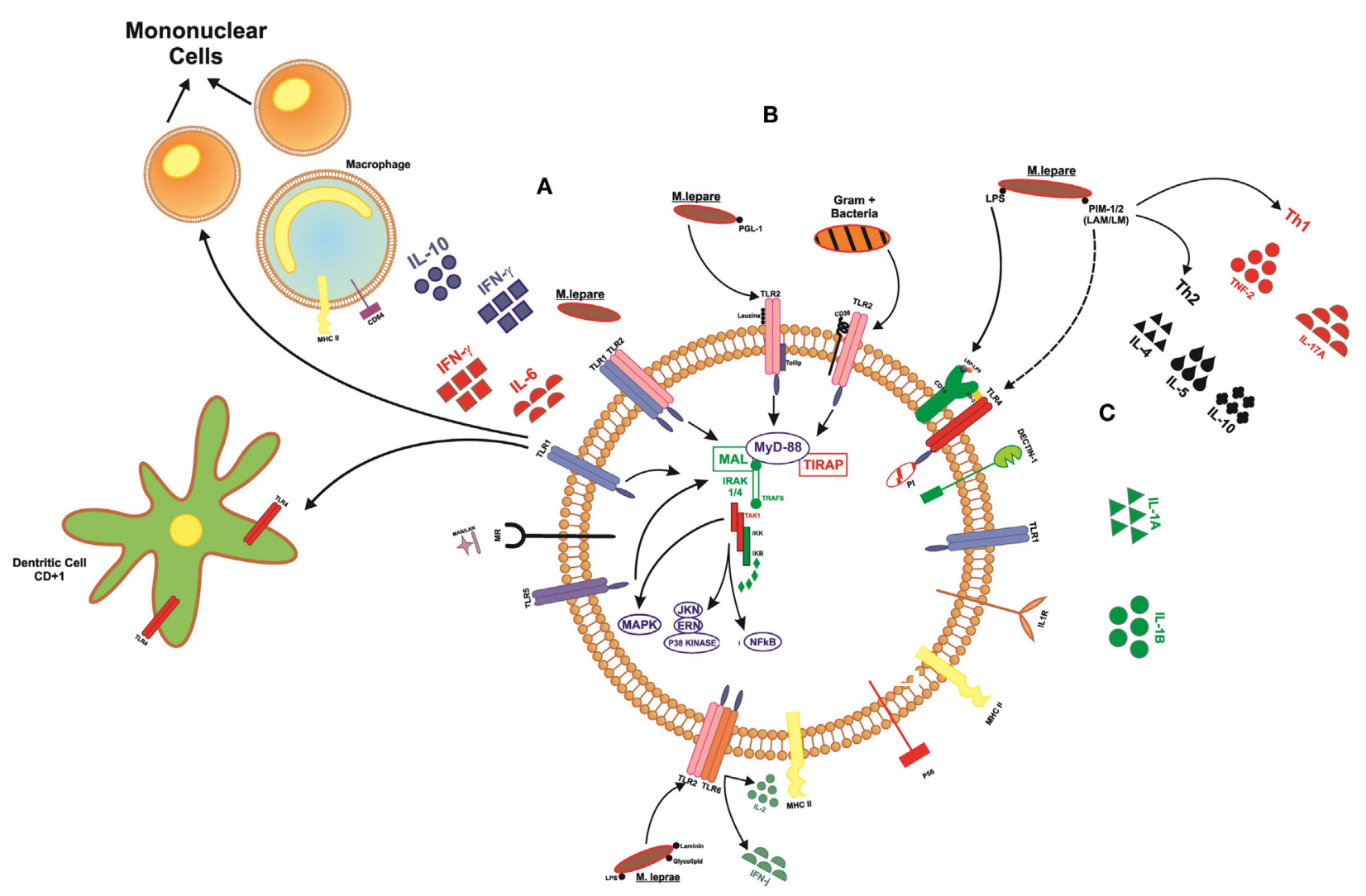

FIGURE 3 | Signaling toll-like receptors and interaction with cells of the immune system. (A) TLR1 acts on the differentiation of mononuclear cells into macrophages, releasing cytokines, such as IFN- $\gamma$ and IL-6, whereas when activated, macrophages can release IFN- $\gamma$ and IL-12. This receiver also operates in the maturation of dendritic cells, which become able to present the peptide to lymphocytes T. (B) TLR2 heterodimer with other markers, such as TLR1, TLR6, CD36, Dectin1, being able to recognize membrane components of bacteria Gram ${ }^{+}$and Gram- (C) TLR4 forms a complex with MD2 in response to LPS. The marker CD14 binds to LPS. This LBP-LPS complex binds and releases the TLR-MD2 complex to initiate intracellular signaling.

frequencies of the NRAMP1 gene in relation to the Mitsuda test among patients and household contacts, nor between those with the $\mathrm{MB}$ and $\mathrm{PB}$ forms of the disease. However, individuals with a negative lepromin response associated with genotype " 22 " or " 23 " presented sevenfold and eightfold greater chances of developing leprosy, respectively (29). A sib-pair linkage analysis between the Mitsuda response and the NRAMP1 gene was done among 20 nuclear families with leprosy from Ho Chi Minh City, Vietnam. All family subjects were genotyped for several intragenic and flanking NRAMP1 markers, leading to the definition of a fully informative NRAMP1 haplotype. Significant linkage was observed between NRAMP1 and Mitsuda reaction when considered either as a quantitative $(P<0.002)$ or as a categorical $(P=0.001)$ trait. Separate analyses among healthy and affected sibs showed evidence for linkage in both subsamples, indicating that linkage between the Mitsuda reaction and NRAMP1 is independent of leprosy status (30).

Hatta et al. determined the association of three polymorphic variants (D543N, 3'UTR, and INT4) of the NRAMP1 gene with tuberculosis and leprosy in 58 tuberculosis patients, 42 leprosy patients and 198 healthy controls from South Sulawesi, Indonesia.
An association of the INT4 polymorphism was observed with the PB type of leprosy (31). In a study conducted in Mali, West Africa, a total of 273 patients with leprosy and 201 controls were genotyped for NRAMP1 polymorphisms previously associated with tuberculosis. No association was found with leprosy per se, but the NRAMP13'UTR polymorphism was associated with leprosy subtypes (32).

The INT4, D543N, and 3'UTR polymorphisms of NRAMP1 were also analyzed by in patients with leprosy from Thailand. There were no significant difference in the distribution of the genotypes and allele frequencies of NRAMP1 polymorphisms between the patients and controls (33). The data from seven multi-case leprosy families (84 individuals) from French Polynesia were analyzed by Roger et al. Nine polymorphic loci and three microsatellite markers (D2S104, D2S173, and D2S1471) within NRAMP1 gene were typed and the results observed suggest that $N R A M P 1$ is not linked to leprosy susceptibility in the French Polynesian families tested (34). Another study analyzed polymorphisms of this gene to investigate susceptibility for leprosy reactions in Recife, Brazil $(274 C / T, D 543 N$, and $1729+55$ del4 polymorphisms of the NRAMP1 gene). The mutant $274 T T$ genotype prevailed in 
cases without reversal and ENL reactions, suggesting the $274 \mathrm{C} / \mathrm{T}$ polymorphism of the NRAMP1 gene in determining the susceptibility to reactions in individuals with leprosy (35). Members of 20 multiplex leprosy families of Vietnam and China $(N=168)$ were genotyped for NRAMP1 alleles and 4 closely linked polymorphic markers and the finding showed that the segregation of NRAMP1 haplotypes into affected siblings was significantly non-random (36).

\section{Mannose Receptor C-Type 1 Gene}

The MRC1 gene, located in the chromosome 10p13 region, encodes the mannose receptor (MR) in humans. TLRs, the nucleotide-binding oligomerization domain (NOD)-2 and $M R C 1$ genes modulate the autophagy and are involved in host-pathogen interactions; they are important in the recognition of mycobacterial peptides and activation of signaling intracellular. A study of Vietnamese families analyzed the G396S polymorphism in exon 7 of the $M R C 1$ gene and suggested that it is a protective factor against leprosy per se and MB leprosy (37). In a Brazilian population, the G396-F407 haplotype was considered a risk factor, while the S396-F407 haplotype was considered a protective factor against leprosy (37). Subsequently, Wang et al. analyzed the polymorphism of genetic variants of the MRC1 and IFNG genes in Han Chinese patients with leprosy. Although the results have not been confirmed, the rs692527 and rs34856358 variants of the $M R C 1$ gene were found to be associated with PB leprosy, and the rs3138557 variant of the IFNG gene was associated with MB leprosy (38).

\section{Cytosolic Receptors: Nucleotide-Binding Oligomerization Domain Protein (NOD1 and NOD2)}

Several studies have correlated autophagy with protecting host against various intracellular bacteria that use different strategies to establish infection. After phagocytosis of the infectious agent, different molecules are encoded, such as Toll-like receptors, the cytosolic Nod-like receptors (NLRs), and RIG-I-like receptors (RLRs), all of which are important in the detection of intracellular pathogens. In innate response, the cytosolic sensors belonging to the NLR family are able to perceive disturbances in the membrane caused by microorganisms and directly recognize MDP mycobacterial components. Some NRLs activate NF-kB pathway through inflammasome (ASC/Caspase-1), releasing IL-1 and IL-18, while others NRLs, such as NOD2 activates NF-kB recruiting RIPK2, TRAF, and E3-Ubiquitin, triggering a signaling cascade to activate IFN regulatory factor (IRF) and IKKs, and following of P38, JNK, ERK MAPK activation, releasing IFN $\alpha / \beta$ and other proinflammatory cytokines. NOD1 is able to direct immune response to Gram-negative bacteria, while NOD2 recognizes Gram-negative and Gram-positive (14). Among inflammatory cytokines, NOD2 induce Th17 responses that, in turn, keep the inflammatory response. Th17 cells produce IL-17A, IL-17F, IL-21, and IL-22 as their signature cytokines. IL-17 is correlated with induction of proinflammatory programs associated with chemokine secretion and neutrophil recruitment that cooperate for mycobacterial killing (39). Inflammatory cytokines, such as TNF- $\alpha$, IL-12, and
IL-4, are produced after the recognition of the microorganism and other components as nitric oxide. Thus, the NOD2 plays an important role in the response to microorganisms, helping in the recognition, autophagy, and modulating the immune response.

Several studies have correlated NOD2 gene polymorphisms to leprosy based on its role in the recognition of mycobacteria shortly after signaling mediated by TLRs. Two SNPs in the NOD2 gene were found to be associated with leprosy in a study of 706 Han Chinese patients and 1226 healthy controls: rs9302752 $(\mathrm{OR}=2.28 ; \mathrm{IC}=1.70-3.06)$ and $\mathrm{rs} 7194886(\mathrm{OR}=2.25$; $\mathrm{IC}=1.58-3.21)$ suggesting risk for development of leprosy (40). In India, the rs9302752 SNP was investigated in 211 leprosy patients and 230 controls, but the results were not considered because they were not in Hardy-Weinberg equilibrium (41). The study of Zhang (2009) (40) was replicated in a Chinese population with tuberculosis (1043 patients vs. 808 controls) for the SNPs: rs3135499, rs7194886, rs8057341, and rs9302752 (42). No significant differences were found between the genotype frequencies of patients and controls, although when they analyzed patients with bacteriological confirmation test, the variant rs7194886 showed risk to disease (CT/TT vs. CC: $\mathrm{OR}=1.35$; $\mathrm{IC}=1.05-1.72)(42)$. For the NOD2 SNPs found to be associated with leprosy among Chinese patients (Zhang, 2009) (40), only the rs9302752 SNP was replicated in 474 samples family based from Vietnamese with $\mathrm{PB}$ and MB leprosy ( $N=188$ and $N=286$, respectively) suggesting risk for development of severe form of leprosy $(\mathrm{MB})(P=0.014$; $\mathrm{OR}=1.27 ; \mathrm{IC}=1.27-1.58$ ) (43). Marques et al. (44) describe the results of a validation and replication GWAS study of the Chinese (Zhang, 2009) (40) in Brazilians, using a stepwise strategy that involved two family-based and three independent case-control samples, resulting in 3,614 individuals. Three NOD2 alleles of rs8057341 (A allele, Pc $=0.003)$, rs2111234 (G allele, Pc $=0.031$ ), and rs3135499 (C allele, $\mathrm{Pc}=0.023$ ) were statistically significant in family-based study association, indicating protection to leprosy (44). The replication of the association study between NOD2 rs8057341 in different populations from Brazil (Rondonópolis, Bauru, and Rio de Janeiro) was observed in all case-control samples, with the AA genotype conferring resistance to leprosy $\left(P=1.39 \times 10^{-6} ; \mathrm{OR}=0.49 ; \mathrm{IC}=0.36-0.65\right)$, but the same results were not observed in the family-based study. To obtain an overall estimate, all samples (case-control and family-based studies) were included to build a summary plot that indicated a consensus protective $\mathrm{OR}$ value (A allele $=0.80, P=0.0001$ ), confirming allele A of NOD2 rs8057341 as a leprosy resistance genetic factor (44). Another study in 933 patients (240 patients had reversal reactions and 124 had ENL reactions) of Nepal compared with 101 controls, suggested that NOD2 genetic variants are associated with susceptibility to leprosy and the development of leprosy reactive states. Four polymorphisms were identified as significant $(P<0.05)$ at the allelic level: (rs12448797: OR 2.18; rs2287195: OR 1.51; rs8044354: OR 1.53; and rs1477176: OR $0.44)$. Genotypic analysis revealed that these associations with ENL were significant for seven SNPs suggesting susceptibility to developing of type II reactions: (rs2287195, rs8044354, rs7194886, rs6500328, rs17312836, rs1861759, and rs1861758) (45). Singh et al. examined the occurrence of the three most common polymorphisms in the NOD2 gene (Arg702Trp, Gly908Arg, 
and 3020insC) in patients with mycobacterial diseases, but significant differences were not observed (46). However, a study performed in mononuclear cells of individuals homozygous for the 3020insC NOD2 mutation, showed an $80 \%$ defective cytokine response after stimulation with $M$. tuberculosis. It was also demonstrated that TLR2 and NOD2 mycobacterial ligands synergize for the production of inflammatory cytokines, and that this synergism is lost in cells lacking either of these receptors. The intracellular pathways induced by NOD2 and TLR2 during recognition of mycobacterial components synergize, and the stimulation of cytokine production by $M$. tuberculosis is greatly impaired in individuals with NOD2 mutations (47). Analysis of the sequence variation in the coding regions of the NOD2 gene in the 377 African-American from Houston, TX, USA, patients with tuberculosis and the 187 control subjects identified 56 sequence variants. Transition substitutions were more prevalent (74.5\%) than transversions (25.5\%) among these SNPs. Three SNPs (Pro268Ser, Arg702Trp, and Ala725Gly) demonstrated significant associations with tuberculosis. Minor allele carriers (heterozygous and homozygous) of Pro268Ser ( $\mathrm{OR}=0.55$; $\mathrm{CI}=0.32-0.94 ; P=0.02)$, and $\operatorname{Arg} 702 \operatorname{Trp}(\mathrm{OR}=0.27$; $\mathrm{CI}=0.08-$ $0.88 ; P=0.01)$ presented decreased risks for tuberculosis. Conversely, the minor allele carrier (heterozygous) of Ala725Gly showed an increased risk for tuberculosis disease $(\mathrm{OR}=2.16$; $\mathrm{CI}=1.10-4.72 ; P=0.03)(48)$.

\section{Mannose-Binding Lectin}

Mannose-binding lectin (MBL) is a soluble protein in the serum, which participates in the innate immune response with activation of the complement system and opsonization effects. This protein binds to several pathogens, allowing complementmediated lysis and linkage to membrane of mycobacteria. Many studies found an increase in the concentrations of MBL in leprosy patients $(25,49,50)$.

The genetic analysis of a study developed with a population of Nepal (933 leprosy patients), which examined polymorphisms in the TNF and $M B L$ genes showed the $M B L-G 161 A$ variant associated with protection against LL, and identified a polymorphism associated with low MBL levels (homozygosity of $M B L-G 161 \mathrm{~A}$ ), which was associated with a reduced risk of LL when compared with TT leprosy $(\mathrm{OR}=0.33$; CI95\% $=0.12-0.85, P=0.010)$ (25). In Southern Brazil, the polymorphisms at the promoter and exon 1 regions of the MBL2 gene were assessed on 264 patients with leprosy and 214 matched healthy control subjects and the results showed a decreased frequency of haplotypes/ genotypes associated with low expression of circulating MBL in lepromatous patients when compared with tuberculoid patients. The LYPA haplotype related with high expression of MBL was associated with susceptibility to leprosy per se and to progression to the lepromatous and borderline forms of the disease (51). However, another study in the Brazilian population (228 patients) investigated SNPs of the MBL2 gene and did not find significant differences in genotype and allele frequencies (49). Finally, a recent study, in the Chinese population, analyzed the ficolin-2 (FCN2), mannose-binding lectin (MBL2) and complement factor $\mathrm{H}(\mathrm{CFH})$ genetic variants, which may influence the innate immune response to M. leprae (50).

\section{PARK2/PACRG}

Parkinson's disease is characterized by the participation of the PARK2 gene and its coregulator PACRG both with a length of $2 \mathrm{Mb}$ in the chromosome $6 \mathrm{q} 25.2-\mathrm{q} 27$ region. These genes share a regulatory overlap region of about $5 \mathrm{~kb}$, as well as a common bidirectional promoter (52). The PARK2 and PACRG genes encode proteins that are involved in cellular metabolism of ubiquitination. PARK2 encodes parkin and an ubiquitin E3 ligase that is involved in the release of polyubiquitinated proteins to the proteasome complex. It is suggested that ubiquitin-mediated proteolysis has an important role in the control of infections by M. leprae.

Four SNPs in the promoter region of the PARK2 gene and adjacent to the PACRG gene were found to be associated with leprosy in a study of Vietnamese families. Furthermore, in the same study using a high-density association scan of both genes, 19 SNPs between intron 1 of the PARK2 gene and intron 2 of the PACRG gene showed evidence of association. The study was replicated in the Brazilian population and the findings were confirmed (53). Recently, findings reported by Alter et al. confirm that the SNPs identified in the promoter region of PARK2/PACRG are associated with leprosy in two independent and ethnically distinct samples, thus supporting the evidence that these variants are risk factors for the development of the disease (54). This study evaluated a Vietnamese (198 single cases) and an Indian (364 cases) population and a control group of northern India (370). In the Vietnamese sample, 69 SNPs were associated with leprosy, and as expected, two SNPs (rs1040079 and rs9356058) confirmed the study carried out by Mira et al. (53). In the case-control study in India, three SNPs were also found associated in the Vietnamese population (rs6915128, rs10806768, and rs1333955) (54). However, analysis of 11 previously indicated risk variants and other 2 SNPs (rs13195186 and rs1801474), which are all located in the region of $P A R K 2$ and $P A C R G$, shows no significant association with susceptibility to leprosy per se in the Chinese Population (55). In an Indian population, Malhotra et al. investigated the association of six SNPs present in this regulatory region in 286 leprosy patients and 350 healthy controls and no association with leprosy susceptibility was observed (56).

Recently, conducted a mapping of PARK2 and regulatory region of the $P A C R G$ gene in the north Indian and east IndianOrissa population groups, where 11 of the 96 SNPs studied showed a strong association with susceptibility to leprosy. The results showed 10 SNPs in the region of PARK2: rs9347683 within the core promoter region of PARK2 gene and SNPs rs9347684, rs9346929, rs4709648, rs12215676, rs10806765, rs6936373, rs1333957, rs9365492, and rs9355403, located within $63.8 \mathrm{~kb}$ upstream region of the PARK2 gene and only one SNP (rs10945859), located $6.67 \mathrm{~kb}$ upstream of PACRG gene (57).

\section{Major Histocompatibility Complex Class I Chain-Related Genes}

Major histocompatibility complex class I chain-related genes A (MICA) and $\mathrm{B}(\mathrm{MICB})$ are located on chromosome 6 near to the HLA-B and HLA-C loci. These genes are highly polymorphic producing different MICA and MICB proteins which are induced 
by cellular stress. MICA molecules are recognized by the NKG2D receptor on the surface of $\gamma \delta$ T lymphocytes, $C D 8^{+} \alpha \beta$ T lymphocytes, and NK cells that contribute to defend the organism against infections, including against infection by $M$. leprae $(58,59)$.

To determine the association of MICA gene with leprosy and its subgroups, Wang et al. examined 69 Southern Chinese patients and 112 healthy controls. The frequency of the $M I C A^{\star} A 5$ allele showed a decreasing tendency in the patients with leprosy as compared to the controls, but the difference was not significant. However, the frequency of the $M I C A^{\star} A 5$ allele was significantly decreased in the $\mathrm{MB}$ patients but not in the $\mathrm{PB}$ patients (60). A study analyzed exon 5 of the MICA gene and intron 1 of $M I C B$ in families of Southern India who developed $\mathrm{PB}$ leprosy and showed that $M I C A^{\star} 5 A 5.1, M I C B^{\star} C A 16$ and $M I C B^{\star} C A 19$ were associated with the disease (58). The $M I C A^{\star} 5 A 5.1$ allele, associated with leprosy susceptibility in this much larger study, has a single $\mathrm{G}$ insertion occurring in a background of five alanine repeats causing a frame shift mutation that results in a premature stop codon and a truncated transmembrane domain (61).

Recently, our group conducted a study of MICA genes and leprosy in a population of southern Brazil showing that the $M I C A^{\star} 027$ allele was decreased in leprosy per se and in $\mathrm{MB}$ patients (62). MICA ${ }^{\star} 027$ codifies a transmembrane domain, A5, related to the normal expression of protein associated with protection against, suggesting susceptibility toward leprosy and its most severe form.

\section{Killer Cell Immunoglobulin-Like Receptor Genes}

Natural killer cells, which participate in innate and adaptive immunity, can be cytotoxic when activated by an exaggerated expression of ligands for the activation receptors on the surface of target cells. The KIRs expressed on the surface of NK cells interact with other cells through specific HLA molecule ligands, transmitting activating or inhibitory signals (63). These receptors possess HLA molecules as ligands and can act by activating the cell, through activating receptors, or inhibit the cell through inhibitory KIR. The main HLA ligands are divided into three groups: $\mathrm{C} 1, \mathrm{C} 2$, and Bw4. The HLA ligands of the $\mathrm{C} 1$ Group are characterized by presenting serine at position aa77 (AGC) and asparagine at position aa80 (AAC) and binding to KIR2DS2, KIR2DL2, and KIR2DL3 receptors. The C2 Group is characterized by presenting asparagine at position aa77 (AGC) and lysine at position aa80 (AAA) and binding to the KIR2DS1 and KIR2DL1 receptors. The Bw4 Group acts as a ligand to the KIR3DL1 receptor (64).

A study of KIR and their ligands was carried out in a Brazilian population comparing leprosy patients with a control group for the first time by our group (65). The activating receptor genes KIR2DS2 and KIR2DS3 were found at higher frequencies in the group of patients with tuberculoid leprosy compared to the lepromatous group. The frequency of KIR2DL1 with its ligand C2 $\left(H L A-C^{\star} 02,{ }^{\star} 04,{ }^{\star} 05,{ }^{\star} 06,{ }^{\star} 07,{ }^{\star} 15,{ }^{\star} 17\right.$, and $\left.{ }^{\star} 18\right)$ was lower in the group with the borderline form of the disease, compared to the control group and to patients with tuberculoid form. Moreover, there was a lower frequency of KIR2DL3 with C1 $\left(H L A-C^{\star} 01,{ }^{\star} 03,{ }^{\star} 07,{ }^{\star} 08,{ }^{\star} 12,{ }^{\star} 13,{ }^{\star} 14\right.$, and $\left.{ }^{\star} 16\right)$ in patients with tuberculoid leprosy compared to control individuals, to patients with leprosy per se and to the borderline group (65). Other study realized with population from Rondonópolis, Center-East Brazil, there was a higher frequency of activating KIR genes, KIR2DS1, 2DS2, and 3DS1 and your ligands HLA in the tuberculoid (TT) group as compared to the LL group. In this same study, KIR2DL2/2DL2-C1 was more frequent in the patient, TT and LL groups than in the control group. Higher frequency of inhibitory pairs it was present in Borderline patients when compared to the control group, and a higher frequency of activating pairs as compared to the LL group. It was realized multivariate analysis and confirmed the associations and demonstrated that being a female is a protective factor against the development of the disease per se and the more severe clinical form (66).

\section{Cytokine Genes}

The substitution of a single base in cytokine genes may cause differences in the expression of these molecules generating structural and functional changes which may influence the host's response to a pathogen. Several authors also described polymorphisms of cytokine genes associated with the clinical forms of leprosy (67-70).

Brazilian researchers $(67,69-72)$ found an association between the TNF-308A (rs1800629) allele and a protective effect against the development of leprosy and results similar were also observed in a study in Nepal in 2010 (25). A study performed in Rio de Janeiro by Vanderborght et al. (73) observed the relationship between the A allele in the promoter region of the TNF-308 and a lower bacteriological index (BI), whereas the A allele in the promoter region of the TNF-238 (rs361525) was associated with a higher BI. However, in Mexican population (74), no association was found between TNF-308G/A and leprosy. Some studies have suggested a protective role for TNF- $\alpha$ in TT and BT patients (75). A study, conducted in an Indian population, showed that the frequency of the TNF2 allele (with substitution of $\mathrm{G}>\mathrm{A}$ at position -308 , the TNF gene promoter region) was significantly associated with LL. A Thai study also showed an increase in the frequency of the allele in $\mathrm{MB}$ patients, indicating that this allele in this position induces susceptibility to the more severe forms of the disease (33). However, Levee et al. (76) found no link between $G 1 M, G 2 M, K M, I L 1 B$, TNFA $(1,2)$, and TNFA (A, G) and leprosy when performed a linkage study with six families of French Polynesian. In the multi-case leprosy family study from northeastern of Brazil, the common allele TNFA1 of the -308 promoter region polymorphism showed linkage and/or association with disease per se, at a high level of significance. Two loci transmission disequilibrium testing suggested susceptibility to TNFA1/LTA2 and protective to TNFA2/LTA2 haplotypes in the class III region, suggesting together the segregation and HLA analyses suggest the possibility of more than one susceptibility locus to leprosy in the MHC (68).

A study of an Indian population reported the participation of variants BAT1-LTA-TNF-BTNL2, as risk factors for the development of leprosy (77). According to authors, the combination of low T-cell inhibition status of BTNL2, less inhibition of TNF- $\alpha$ by $B A T 1$, and low TNF- $\alpha$ expression may provide protection from leprosy, which may be stronger in the presence of high 
TNF- $\alpha$ producer allele genetic background (77). SNPs located at BAT1 (HLA-B-associated transcript 1) promoter and $13 \mathrm{~kb}$ upstream to LTA gene affected the transcription factor binding site; hence, the gene expression. BAT1 protein is also known to down regulate pro-inflammatory cytokines, such as TNF- $\alpha$, IL-1, and IL-6 (78).

IFN- $\gamma$, a cytokine secreted by Th $1 \mathrm{CD} 4^{+}, \mathrm{CD} 8^{+} \mathrm{T}$ cells, and NK cells, acts in the body's defense against intracellular pathogens. A study in a Brazilian population showed that the $\mathrm{T}$ allele at position +874 of the IFNG gene conferred a protective effect to leprosy (79), but, Wang et al. (38) found no association between IFNG + 874T/A and leprosy in Chinese patients. Nevertheless, the variant rs3138557 in the IFNG gene had many CA repeat alleles and they observed that the alleles IFNG (10CA), IFNG (13CA), and IFNG (15CA) had a higher frequency in patients, especially in $\mathrm{MB}$, and that the allele IFNG (17CA) was more frequent in $\mathrm{PB}$ patients. In Brazilian patients from Amazonas state, there were no significant differences between patients and control group. Though, the A/A genotype and the allele IFNG (16CA) were significantly associated with $\mathrm{PB}$ compared to MB patients (80). In another population of the same country, Reynard et al. (81) observed that a higher frequency of alleles IFNG (15CA), IFNG (16CA), and IFNG (17CA) was associated with development of leprosy, which indicates that the IFNG gene polymorphism may contribute to the course of infection.

Interleukin-6 (IL-6) is a pleiotropic cytokine that plays an important role in a wide range of processes, such as immune response, acute phase reactions, and hematopoiesis (82). In a case-control study (83) was observed a correlation between plasma levels of IL- 6 and IL6 genotypes in patients with Type- 2 reactions in leprosy. Thus, the identification of genetic factors predictive of leprosy reactions could contribute on prevention strategies.

Interleukin-12 consists of two covalently linked subunits: p35 and $\mathrm{p} 40$. The effects of IL-12 are mainly controlled by the level of transcription of $\mathrm{p} 40$ and expression of IL-12R. IL-12 is produced quickly after infection and acts as a proinflammatory cytokine by inducing IFN- $\gamma$ production and enhancing the proliferation and cytotoxicity of NK and T cells (84). In Indian patients (85), subjects with leprosy were less likely to have the $3^{\prime}$ UTR genotype associated with lower IL-12B expression. In a study in Western Mexico (86), it was found that the $1188 \mathrm{~A} / \mathrm{C}$ polymorphism in the $3^{\prime}$ UTR of IL12p40 gene was associated with greater susceptibility to LL, without regard to the expression levels of IL-12 p40. On the other hand, Jesús Salvador et al. (87) in a study with Mexican patients found no significant association between genotype and allele frequencies of the $1188 \mathrm{~A} / \mathrm{C}$ polymorphism and LL (87). Liu et al. conducted a multiple-stage genetic association study in leprosy patients from China and observed associations implicating IL18RAP/IL18R1 and IL12B as susceptibility genes for leprosy (88). In another study, Ali et al. observed that SNP rs2853694 (A/C at intron 3) in IL12B gene showed a positive association with leprosy in Indian patients (89).

Interleukin 10 (IL-10) is a cytokine produced by monocytes and activated T cells. It is deeply involved in the regulation of inflammatory and immunological reactions. Several polymorphisms have been observed in the IL10 gene, including 6-11 CA repeats microsatellite polymorphisms, and three point mutations: -1082 (G/A) (rs1800896), -819 (C/T) (rs1800871), and -592 (C/A) (rs1800872) (90).

In Mexican patients (74), no significant difference was found in the frequency of IL10-819C allele in patients and controls. Nevertheless, in a Brazilian population (91), the IL10-819T allele was associated with leprosy in both a case-control study and in a meta-analysis. In another Brazilian population (69), where the IL10-819TT genotype was significantly higher in patients than in healthy controls and the frequency of the IL10-819T SNP was greater in $\mathrm{PB}$ patients compared to $\mathrm{MB}$ or among control subjects. However, the genotypes $\mathrm{C} / \mathrm{C}$ and $\mathrm{C} / \mathrm{T}$ in the SNP -819 and $\mathrm{C} / \mathrm{C}$ and $\mathrm{C} / \mathrm{A}$ in the $-592 \mathrm{SNP}$ were positively associated with leprosy in a Colombian population. The haplotypes -819C-592C and -1082A-819C-592C showed significant association (92). In another study (93) with Brazilian patients, the haplotype IL10-3575A/-2849G/-2763C was associated with resistance to leprosy and development of more severe forms of the disease, and the haplotype IL10-3575T/-2849A/2763C with susceptibility to LD. Malhotra et al. (94) in a Indian population observed that the extended haplotype IL10-3575T/-2849G/-2763C/$1082 \mathrm{~A} /-819 \mathrm{C} /-592 \mathrm{C}$ conferred resistance to leprosy per se and to development of more severe forms of disease, whereas the haplotype IL10-3575T/-2849G/-2763C/-1082A/-819T/-592A was associated with the risk of severe form of the disease. A study performed in a population of Southern Brazil, Franceschi et al. (70) showed a lower frequency of haplotype IL10-1082G/-819C/$592 \mathrm{C}$ in patients with the LL form compared to the control group. These studies suggest the involvement of SNPs in the promoter region of the IL 10 gene in leprosy.

\section{CD14}

Some components of mycobacteria, as PGL-1, are recognized by TLR1/2 heterodimer, while the LPS, present in abundance in the membrane of $M$. leprae, is transferred by $\mathrm{CD} 14$ associated with lipopolysaccharide-binding protein (LBP) to the TLR4/MD2 complex. Thereby, it initiates the signaling for intracellular activation of NF- $\mathrm{kB}$, with consequent production of interferon (IFN) and other cytokines, such as IL-6, TNF- $\alpha$, and IL- $1(9,10,14)$.

CD14 exists in two forms, its soluble form, sCD14, and mCD14, the cell membrane form. sCD14 may be produced by monocytes, hepatocytes and endothelial cells and the functional relevance of SCD14 is its mediation of bacteria-induced cell activation of mCD14 expressing cells $(95,96)$. In addition to the recognition and internalization of LPS, the differentiation of monocytes to macrophages is accompanied by regulation of CD14 and data suggest that CD14 is essential for TNF- $\alpha$ production, this being the most proinflammatory cytokine produced during bacterial infection. In combination with the TLR4/MD2 complex, CD14 recognize LPS, resulting in a proinflammatory immune response through TIRAP-MyD88-dependent and TRAM-TRIF dependent TLR4 activation pathways $(97,98)$. The TLR4 is a signaling receptor to LPS and MD2 is a coprotein required to intracellular signaling TLR4 (99).

CD14-159 C/T polymorphism was investigated in several populations with tuberculosis $(95,100-104)$. A meta-analysis was performed with this marker and $-159 \mathrm{~T}$ allele was associated with 
TABLE 1 | Summary of associations between genes of innate immune response TLR, NOD2, PARK2, PACRG, and leprosy.

\begin{tabular}{|c|c|c|c|c|c|c|c|}
\hline Genes & Population & SNP genotype/(risk allele) & Phenotype & Compared to & OR/(rr) & $P$-value & Conclusion \\
\hline TLR1 & Bangladeshi & N248S/SS/rs4833095 & Per se & Controls & 1.34 & 0.012 & Susceptibility (14) \\
\hline TLR1 & Bangladeshi & N248S/SN/rs4833095 & Per se & Controls & 0.78 & 0.015 & Protection (14) \\
\hline TLR1 & Bangladeshi & N248S/SS/rs4833095 & ENL & Without ENL & 0.21 & - & Protection (14) \\
\hline TLR1 & Indian (New Delhi) & I602S/rs5743618 & Per se & Controls & 0.27 & $1.3 \times 10^{-6}$ & Protection (15) \\
\hline TLR1 & Indian (Kolkata) & I602S/SS/rs5743618 & Per se & Controls & 0,40 & 0.012 & Protection (15) \\
\hline TLR1 & Turkish & I602S/SS/rs5743618 & Per se & Controls & 0.48 & 0.004 & Protection (15) \\
\hline TLR1 & Brazilian & N248S/SS/rs4833095 & Per se & Controls & 1.81 & 0.004 & Susceptibility (16) \\
\hline TLR2 & Ethiopian & N199N/rs3804099 & $\mathrm{RR}$ & Controls & 5.83 & 0.001 & Susceptibility (19) \\
\hline TLR4 & Ethiopian & $\begin{array}{l}\text { A299G/rs4986790-T390I/ } \\
\text { rs4986791 }\end{array}$ & Per se & Controls & $0.34 / 0.16$ & 0.001 & Protection (21) \\
\hline NOD2 & Chinese & rs9302752 & Leprosy & Controls & 2.28 & $1.42 \times 10^{-9}$ & Susceptibility (40) \\
\hline NOD2 & Chinese & rs7194886 & Leprosy & Controls & 2.25 & $4.43 \times 10^{-7}$ & Susceptibility (40) \\
\hline NOD2 & Vietnamese & rs9302752 & Leprosy (family) & - & 1.17 & 0.014 & Susceptibility (43) \\
\hline NOD2 & Vietnamese & rs9302752 & MB (family) & - & 1.30 & 0.036 & Susceptibility (43) \\
\hline NOD2 & Brazilian & rs8057341 & Leprosy (family) & - & - & 0.003 & Protection (44) \\
\hline NOD2 & Brazilian & rs2111234 & Leprosy (family) & - & - & 0.031 & Protection (44) \\
\hline NOD2 & Brazilian & rs3135499 & Leprosy (family) & - & - & 0.023 & Protection (44) \\
\hline NOD2 & Brazilian & rs8057341-genotype AA & Leprosy & Controls & 0.49 & $1.39 \times 10^{-6}$ & Protection (44) \\
\hline NOD2 & Brazilian & rs8057341-allele A & Leprosy and family & Controls & 0.80 & 0.0001 & Protection (44) \\
\hline NOD2 & Nepalese & rs12448797 & Leprosy & Controls & 3.20 & 0.016 & Susceptibility (45) \\
\hline NOD2 & Nepalese & rs2287195 & Leprosy & Controls & 2.29 & 0.001 & Susceptibility (45) \\
\hline NOD2 & Nepalese & rs8044354 & Leprosy & Controls & 2.17 & 0.001 & Susceptibility (45) \\
\hline NOD2 & Nepalese & rs8043770 & Leprosy & Controls & 2.05 & 0.004 & Susceptibility (45) \\
\hline NOD2 & Nepalese & rs13339578 & Leprosy & Controls & 2.19 & 0.001 & Susceptibility (45) \\
\hline NOD2 & Nepalese & rs4785225 & Leprosy & Controls & 2.00 & 0.004 & Susceptibility (45) \\
\hline NOD2 & Nepalese & rs751271 & Leprosy & Controls & 1.95 & 0.005 & Susceptibility (45) \\
\hline NOD2 & Nepalese & rs1477176 & Leprosy & Controls & - & 0.0005 & Susceptibility (45) \\
\hline NOD2 & Nepalese & rs8044354 & ENL & (MB) without ENL & 1.34 & 0.05 & Susceptibility (45) \\
\hline NOD2 & Nepalese & rs17312836 & ENL & (MB) without ENL & 1.43 & 0.039 & Susceptibility (45) \\
\hline NOD2 & Nepalese & rs1861759 & ENL & (MB) without ENL & 1.42 & 0.037 & Susceptibility (45) \\
\hline NOD2 & Nepalese & rs1861758 & ENL & (MB) without ENL & 1.41 & 0.047 & Susceptibility (45) \\
\hline NOD2 & Nepalese & rs1131716 & LL & Controls & 2.01 & 0.013 & Susceptibility (45) \\
\hline NOD2 & Nepalese & rs2287195 & $\mathrm{RR}$ & (PB) without RR & 0.70 & 0.049 & Protection (45) \\
\hline NOD2 & Nepalese & rs8043770 & $\mathrm{RR}$ & (PB) without $\mathrm{RR}$ & 0.68 & 0.028 & Protection (45) \\
\hline NOD2 & Nepalese & rs7194886 & $\mathrm{RR}$ & (PB) without $R R$ & 0.63 & 0.018 & Protection (45) \\
\hline NOD2 & Nepalese & rs1861759 & $\mathrm{RR}$ & (PB) without RR & 0.66 & 0.027 & Protection (45) \\
\hline PARK2 & Brazilian & PARK2_e01 (-2599) allele T & Leprosy & Controls & - & 0.0003 & Susceptibility (53) \\
\hline PARK2 & Vietnamese & PARK2_e01 (-2599) allele T & Leprosy & Controls & - & 0.0006 & Susceptibility (53) \\
\hline PARK2 & Brazilian & rs1040079 (allele C) & Leprosy & Controls & - & 0.001 & Susceptibility (53) \\
\hline PARK2 & Vietnamese & rs1040079 (allele C) & Leprosy & Controls & - & 0.004 & Susceptibility (53) \\
\hline $\begin{array}{l}\text { PARK2/ } \\
\text { PARCRG }\end{array}$ & Vietnamese & rs1333955 (C) & Leprosy & Controls & - & 0.0007 & Susceptibility (53) \\
\hline $\begin{array}{l}\text { PARK2/ } \\
\text { PARCRG }\end{array}$ & Brazilian & rs1333955 (C) & Leprosy & Controls & - & 0.034 & Susceptibility (53) \\
\hline $\begin{array}{l}\text { PARK2/ } \\
\text { PARCRG }\end{array}$ & Vietnamese & rs1333955 (C) & Leprosy (family) & - & - & 0.004 & Susceptibility (54) \\
\hline $\begin{array}{l}\text { PARK2/ } \\
\text { PARCRG }\end{array}$ & Indian & rs1333955 (C) & Leprosy & Controls & - & 0.011 & Susceptibility (54) \\
\hline $\begin{array}{l}\text { PARK2/ } \\
\text { PARCRG }\end{array}$ & Vietnamese & rs10806768 (A) & Leprosy (family) & - & - & 0.012 & Susceptibility (54) \\
\hline $\begin{array}{l}\text { PARK2/ } \\
\text { PARCRG }\end{array}$ & Indian & rs10806768 (A) & Leprosy & Controls & - & 0.0438 & Susceptibility (54) \\
\hline $\begin{array}{l}\text { PARK2/ } \\
\text { PARCRG }\end{array}$ & Vietnamese & rs6915128 (A) & Leprosy (family) & - & - & 0.009 & Susceptibility (54) \\
\hline $\begin{array}{l}\text { PARK2/ } \\
\text { PARCRG }\end{array}$ & Indian & rs6915128 (A) & Leprosy & Controls & - & 0.0455 & Susceptibility (54) \\
\hline PARCG & Indian & rs10945859 (C) & Leprosy & Controls & 1.32 & 0.0039 & Susceptibility (57) \\
\hline PARK2 & Indian & rs9347683 (C) & Leprosy & Controls & 1.31 & 0.0056 & Susceptibility (57) \\
\hline
\end{tabular}


TABLE 1 | Continued

\begin{tabular}{|c|c|c|c|c|c|c|c|}
\hline Genes & Population & SNP genotype/(risk allele) & Phenotype & Compared to & OR/(rr) & $P$-value & Conclusion \\
\hline PARK2 & Indian & rs9347684 (C) & Leprosy & Controls & 1.29 & 0.0083 & Susceptibility (57) \\
\hline PARK2 & Indian & rs9346929 (A) & Leprosy & Controls & 1.31 & 0.0047 & Susceptibility (57) \\
\hline PARK2 & Indian & rs4709648 (C) & Leprosy & Controls & 1.23 & 0.055 & Susceptibility (57) \\
\hline PARK2 & Indian & rs12215676 (C) & Leprosy & Controls & 1.28 & 0.013 & Susceptibility (57) \\
\hline PARK2 & Indian & rs10806765 (T) & Leprosy & Controls & 1.32 & 0.0039 & Susceptibility (57) \\
\hline PARK2 & Indian & rs6936373 (G) & Leprosy & Controls & 1.26 & 0.023 & Susceptibility (57) \\
\hline PARK2 & Indian & rs1333957 (A) & Leprosy & Controls & 1.32 & 0.0034 & Susceptibility (57) \\
\hline PARK2 & Indian & rs9365492 (C) & Leprosy & Controls & 1.39 & 0.00036 & Susceptibility (57) \\
\hline PARK2 & Indian & rs9355403 (A) & Leprosy & Controls & 1.31 & 0.0047 & Susceptibility (57) \\
\hline
\end{tabular}

MB, multibacillary; PB, paucibacillary; BB, mid-borderline; BL, borderline lepromatous; BT, borderline tuberculoid; LL, lepromatous leprosy; $T T$, tuberculoid leprosy; per se, Leprosy independent of specific clinical manifestations; ENL, type 2 reactions or erythema nodosum leprosum; RR, Type I or reversal reaction; NR, leprosy who did not have reaction; UTR, untranslated region; OR, odds ratio; rr, relative risk; P values; SNPs, single-nucleotide polymorphisms; family, family-based association studies.

TABLE 2 | Summary of associations between genes of innate immune response MBL2, VDR, NRAMP1, MRC1, and leprosy.

\begin{tabular}{|c|c|c|c|c|c|c|c|}
\hline Genes & Population & SNP/genotype/(allele) & Phenotype & Compared to & OR/(rr) & $P$-value & Conclusion \\
\hline MBL2 & Nepalese & G161A/rs1800450 & LL & Controls & 0.33 & 0.010 & Protection (25) \\
\hline MBL2 & Brazilian & LYPAY16577 & Leprosy & Controls & 2.25 & 0.003 & Susceptibility (51) \\
\hline MBL2 & Brazilian & LYPAY16577 & $\mathrm{LL}$ & Controls & 2.2 & 0.008 & Susceptibility (51) \\
\hline MBL2 & Brazilian & LYPAY16577 & $\mathrm{BB}$ & Controls & 2.98 & 0.008 & Susceptibility (51) \\
\hline MBL2 & Chinese & (GC) rs11003125 & $\mathrm{MB}$ & Controls & 0.687 & 0.031 & Protection (50) \\
\hline MBL2 & Chinese & (GC) rs7096206 & PB & Controls & 1.416 & 0.038 & Susceptibility (50) \\
\hline MBL2 & Chinese & (AA) rs7100749 & MB & Controls & 9.091 & 0.044 & Susceptibility (50) \\
\hline MBL2 & Chinese & (GA) rs7100749 & PB & Controls & 0.458 & 0.004 & Protection (50) \\
\hline MBL2 & Chinese & (AC) rs11003124 & Leprosy & Controls & 1.357 & 0.038 & Susceptibility (50) \\
\hline MBL2 & Chinese & (C) rs11003124 & Leprosy & Controls & 1.401 & 0.007 & Susceptibility (50) \\
\hline MBL2 & Chinese & (C) rs11003124 & $\mathrm{MB}$ & Controls & 1.458 & 0.010 & Susceptibility (50) \\
\hline VDR & Brazilian & Taql“tt”rs731236 & Leprosy & $\mathrm{MT}(-)$ & 13.33 & - & Susceptibility (22) \\
\hline$V D R$ & Mexican & Taql“TT”rs731236 & $\mathrm{LL}$ & Controls & 1.82 & 0.040 & Susceptibility (26) \\
\hline VDR & Indian & Taql“tt”rs731236 & $\pi$ & Controls & 3.22 & 0.001 & Susceptibility (23) \\
\hline$V D R$ & Indian & Taql“TT”rs731236 & LL & Controls & 1.67 & 0.03 & Susceptibility (23) \\
\hline$V D R$ & Indian & Taql“Tt”rs731236 & $\mathrm{LL}$ and $\Pi \mathrm{T}$ & Controls & 0.58 & 0.008 & Protection (23) \\
\hline VDR & Malawi & Taql“tt”rs731236 & Leprosy & Controls & 4.3 & 0.004 & Susceptibility (27) \\
\hline$V D R$ & Nepalese & Fok-1/rs2228570 & $\mathrm{RR}$ & Without RR & 1.31 & 0.032 & Susceptibility (25) \\
\hline NRAMP1 & Brazilian & Genotype 23 & Leprosy/MT (-) & $\mathrm{HC} / \mathrm{MT}(-)$ & 8.09 & - & Susceptibility (29) \\
\hline NRAMP1 & Brazilian & Genotype 22 and 23 & Leprosy/MT (-) & $\mathrm{HC} / \mathrm{MT}(-)$ & 7.03 & - & Susceptibility (29) \\
\hline NRAMP1 & Vietnamese & - & Mitsuda & TDT & - & 0.002 & Susceptibility (30) \\
\hline NRAMP1 & Indonesian & INT4/469 + 14 & PB & Controls & 2.975 & 0.032 & Susceptibility (31) \\
\hline NRAMP1 & Malian & 3-UTR/1729 + 55del4 & $\mathrm{MB}$ & $\mathrm{PB}$ & 5.79 & 0.003 & Susceptibility (32) \\
\hline NRAMP1 & Brazilian & $274 \mathrm{C} / \mathrm{T}(\mathrm{TT})$ & $\mathrm{ENH}$ & Controls & - & 0.04 & Susceptibility (35) \\
\hline MRC1 & Vietnamese & G396S/rs1926736 & Per se & Controls & 0.76 & 0.035 & Protection (37) \\
\hline MRC1 & Vietnamese & G396S/rs1926736 & $\mathrm{MB}$ & Controls & 0.71 & 0.034 & Protection (37) \\
\hline$M R C 1$ & Brazilian & G396Srs1926736 & Per se & Controls & 1.34 & 0.016 & Susceptibility (37) \\
\hline MRC1 & Brazilian & G396Srs1926736 & $\mathrm{MB}$ & Controls & 1.42 & 0.023 & Susceptibility (37) \\
\hline MRC1 & Brazilian & L407Frs2437257 & Per se & Controls & 0.75 & 0.09 & Protection (37) \\
\hline MRC1 & Brazilian & L407F rs2437257 & $\mathrm{MB}$ & Controls & 0.63 & 0.04 & Protection (37) \\
\hline MRC1 & Chinese & (CT) rs692527 & PB & Controls & 0.598 & 0.022 & Susceptibility (38) \\
\hline MRC1 & Chinese & (TT) rs34856358 & PB & Controls & 1.688 & 0.022 & Susceptibility (38) \\
\hline
\end{tabular}

MB, multibacillary; PB, paucibacillary; BB, mid-borderline; BL, borderline lepromatous; BT, borderline tuberculoid; LL, lepromatous leprosy; $T T$, tuberculoid leprosy; per se, leprosy independent of specific clinical manifestations; ENL, type 2 reactions or erythema nodosum leprosum; RR, type I or reversal reaction; NR, leprosy who did not have reaction; UTR, untranslated region; OR, odds ratio; rr, relative risk; P values; SNPs, single-nucleotide polymorphisms; HC, healthy contacts; MT (-), Negative Mitsuda test.

risk of development of the disease $(\mathrm{OR}=1.27$; $\mathrm{IC}=1.01-1.61)$. The genotype TT also suggests risk when compared to genotype $\mathrm{CT}$ and $\mathrm{CC}(\mathrm{OR}=1.52 ; \mathrm{IC}=1.11-2.08)$. The results of this metaanalysis suggest that CD14 -159C/T polymorphism is associated with a predisposition to the development of tuberculosis (105).
Pacheco et al. analyzed the $-159 \mathrm{C} / \mathrm{T}$ polymorphism in patients with tuberculosis and a control group of Medellin, Colombia (267 patients vs. 112 controls) but did not find significant results for this polymorphism (95). Another study examined polymorphisms in NRAMP -INT4, MBL genes (codons 52, 54, and 57) and CD14 
TABLE 3 | Summary of associations between genes of innate immune response MICA, MICB, KIR, TNF, LTA, BAT1, IFNG, and leprosy.

\begin{tabular}{|c|c|c|c|c|c|c|c|}
\hline Genes & Population & SNP allelic group/genotype ID & Phenotype & Compared to & OR/(rr) & $P$-value & Conclusion \\
\hline MICA & Chinese & $\mathrm{MICA}^{*} \mathrm{~A} 5$ & $\mathrm{MB}$ & Controls & $(0.52)$ & $<0.05$ & Protection (60) \\
\hline MICA & Indian & $\mathrm{MICA}^{\star} 5 \mathrm{~A} 5.1$ & Leprosy (family) & - & - & 0.006 & Susceptibility (58) \\
\hline MICA/MICB & Indian & $\mathrm{MICB}^{\star} \mathrm{CA} 16$ & Leprosy (family) & - & - & 0.031 & Susceptibility (58) \\
\hline MICA/MICB & Indian & $\mathrm{MICB}^{\star} \mathrm{CA} 19$ & Leprosy (family) & - & - & 0.021 & Susceptibility (58) \\
\hline MICA/MICB & Indian & $\mathrm{MICB}^{\star} \mathrm{CA} 21$ & Leprosy (family) & - & - & 0.015 & Protection (58) \\
\hline MICA & Brazilian & $\mathrm{MICA}^{\star} 027$ & Leprosy & Controls & 0.37 & 0.02 & Protection (62) \\
\hline MICA & Brazilian & $\mathrm{MICA}^{*} 027$ & $\mathrm{MB}$ & Controls & 0.27 & 0.01 & Protection (62) \\
\hline MICA & Brazilian & $\mathrm{MICA}^{*} 010$ & $\mathrm{MB}$ & Controls & 0.35 & 0.05 & Protection (62) \\
\hline$K I R$ & Brazilian & KIR2DS3 & $\pi$ & LL & 2.72 & 0.0422 & Susceptibility (65) \\
\hline$K I R$ & Brazilian & KIR2DL1-C2 & BB & Controls & 0.48 & 0.0350 & Protection (65) \\
\hline$K I R$ & Brazilian & KIR2DL1-C2 & $\mathrm{BB}$ & $\pi$ & 0.30 & 0.0197 & Protection (65) \\
\hline$K I R$ & Brazilian & KIR2DL3-C1 & $\pi$ & Controls & 0.43 & 0.0231 & Protection (65) \\
\hline$K I R$ & Brazilian & KIR3DL2-A3/11 & $\mathrm{BB}$ & Controls & 2.04 & 0.048 & Susceptibility (65) \\
\hline$K I R$ & Brazilian & KIR2DL1 & Leprosy & Controls & 0.3 & 0.014 & Protection (66) \\
\hline$K I R$ & Brazilian & KIR2DL1 & $\mathrm{BB}$ & Controls & 0.2 & 0.014 & Protection (66) \\
\hline$K I R$ & Brazilian & KIR2DS2-C1 & Leprosy & Controls & 1.4 & 0.031 & Susceptibility (66) \\
\hline$K I R$ & Brazilian & KIR2DS2-C1 & $\pi$ & Controls & 1.9 & 0.045 & Susceptibility (66) \\
\hline KIR & Brazilian & KIR2DL2-C1 & Leprosy & Controls & 2.6 & 0.024 & Susceptibility (66) \\
\hline$K I R$ & Brazilian & KIR2DL2-C1 & $\pi$ & Controls & 4.1 & 0.045 & Susceptibility (66) \\
\hline$K I R$ & Brazilian & KIR2DL2-C1 & $\mathrm{LL}$ & Controls & 7.5 & 0.032 & Susceptibility (66) \\
\hline TNF & Thailand & TNF-G-308 (A) & Leprosy & Controls & 0.52 & 0.016 & Protection (25) \\
\hline TNF & Thailand & TNF-308 (G/A) & Leprosy & Controls & 2.69 & 0.04 & Susceptibility (33) \\
\hline TNF & Thailand & TNF-308 (A) & $\mathrm{MB}$ & Controls & 2.93 & 0.04 & Susceptibility (33) \\
\hline TNF & Brazilian & TNF-308 & Per se (family) & - & - & 0.000001 & Susceptibility (68) \\
\hline TNF/LTA & Brazilian & $\mathrm{TNF}^{\star} 1 / \mathrm{LTA}^{*} 2$ & Per se (family) & - & - & 0.014 & Susceptibility (68) \\
\hline TNF/LTA & Brazilian & $\mathrm{TNF}^{\star} 2 / \mathrm{LTA}^{\star} 2$ & Per se (family) & - & - & 0.001 & Protection (68) \\
\hline BAT1 & Indian & rs2523504 & Leprosy & Controls & 1.48 & $2.5 \times 10^{6}$ & Susceptibility (77) \\
\hline LTA & Indian & rs13192469 & Leprosy & Controls & 1.58 & $7.2 \times 10^{7}$ & Susceptibility (77) \\
\hline TNF & Indian & rs1800610 & Leprosy & Controls & 1.45 & $2.8 \times 10^{4}$ & Susceptibility (77) \\
\hline IFNG & Brazilian & $\mathrm{IFNG}+874(\mathrm{~T}) \mathrm{rs} 2430561$ & Leprosy & Controls & 0.75 & 0.005 & Protection (79) \\
\hline IFNG & Chinese & $(10 \mathrm{CA})$ rs3138557 & Leprosy & Controls & 4.202 & 0.001 & Susceptibility (38) \\
\hline IFNG & Chinese & (13CA) rs3138557 & $\mathrm{MB}$ & Controls & 1.435 & 0.026 & Susceptibility (38) \\
\hline IFNG & Chinese & $(15 \mathrm{CA})$ rs3138557 & MB & Controls & 1.369 & 0.007 & Susceptibility (38) \\
\hline IFNG & Chinese & $(17 \mathrm{CA})$ rs3138557 & PB & Controls & 2.239 & 0.040 & Susceptibility (38) \\
\hline IFNG & Brazilian & $\mathrm{IFNG}+874(\mathrm{AA})$ & $\mathrm{PB}$ & $\mathrm{MB}$ & 1.62 & 0.028 & Susceptibility (80) \\
\hline IFNG & Brazilian & alleles 5,6 , and 7 & $\pi$ & Controls & - & 0.013 & Susceptibility (81) \\
\hline
\end{tabular}

MB, multibacillary; PB, paucibacillary; BB, mid-borderline; BL, borderline lepromatous; BT, borderline tuberculoid; LL, lepromatous leprosy; $T T$, tuberculoid leprosy; per se, Leprosy independent of specific clinical manifestations; ENL, type 2 reactions or erythema nodosum leprosum; RR, type I or reversal reaction; NR, leprosy who did not have reaction; UTR, untranslated region; OR, odds ratio; rr, relative risk; P values; SNPs, single-nucleotide polymorphisms; Family, family-based association studies.

$-159 \mathrm{C} / \mathrm{T}$ in patients with tuberculosis in the Caucasian population from Poland, and although it has not obtained statistically significant results, suggested the involvement of CD14 and MBL molecules in the host-mycobacteria interactions on the basis of the significant increase in the serum CD14 and MBL in patients with tuberculosis (100). The same polymorphism (-159C/T) was analyzed in Mexican population, simultaneously with the TLR4 expression on the surface of monocytes. Higher levels of $\mathrm{mCD} 14 / \mathrm{sCD} 14$ and TLR4 were observed in tuberculosis patients compared with the control group $(P<0.05)$. The frequency of CD14 -159TT genotype was higher in patients than in control group (35.6 vs. $12.3 \%$ ). Patients who were homozygous for the $\mathrm{T}$ allele had a significantly higher risk for the development of pulmonary tuberculosis $(\mathrm{OR}=2.26)(106)$. In a Korean population (274 tuberculosis patients and 422 healthy controls), the frequency of -159TT genotypes was found higher in tuberculosis patients than in healthy controls. Serum sCD14 levels were higher among tuberculosis patients with -159TT genotypes than among those with -159CC genotypes and IFN- $\gamma$ release by PBMCs was decreased in subjects with -159TT genotypes (101).

In Chinese population (432 Chinese patients with tuberculosis and 404 controls), two positions were analyzed: CD14 -1145 and CD14 -159. Both the frequency of allele $\mathrm{T}$ in the -159 polymorphism $(\mathrm{OR}=1.4)$ and $\mathrm{G}$ allele in the $-1145(\mathrm{OR}=1.51)$ were significantly more frequent in cases than in controls (102). This study confirms the findings in other populations, such as the Americans (107), the Singaporeans (108), and the Chinese (109).

In a case-control study with 698 patients tuberculosis and 404 controls in the Han Chinese population, SNPs in the promoter region do CD14 gene were analyzed: G1619A, T1359G, A1145G, and C159T, but statistically significant differences were found just for the SNP A1145G (OR = 1.5; 64.00 vs. 53.13\%, $P<0.001$, $\mathrm{CI}=1.236-1.849)$, and SNP C159T $(\mathrm{OR}=1.4 ; P=0.001,63.53$ vs. $55.44 \%$, $\mathrm{CI}=1.148-1.708)$ (102). In a Turkish population 
TABLE 4 | Summary of associations between genes of interleukins and leprosy.

\begin{tabular}{|c|c|c|c|c|c|c|c|}
\hline Genes & Population & SNP allelic group/genotype ID/haplotype & Phenotype & Compared to & OR/(rr) & $P$-value & Conclusion \\
\hline IL-6 & Brazilian & (CC) rs1800795 & ENL & NR & 2.41 & 0.03 & Susceptibility (83) \\
\hline IL-6 & Brazilian & $(C C+C G) r s 1800795$ & ENL & NR & 3.71 & 0.005 & Susceptibility (83) \\
\hline IL-6 & Brazilian & (AA) rs2069832 & ENL & NR & 2.71 & 0.007 & Susceptibility (83) \\
\hline IL-6 & Brazilian & $(A A+A G) r s 2069832$ & ENL & NR & 4.00 & 0.002 & Susceptibility (83) \\
\hline IL-6 & Brazilian & (GG) rs2069840 & ENL & NR & 0.44 & 0.03 & Protection (83) \\
\hline IL-6 & Brazilian & $(G G+C G) r s 2069840$ & ENL & NR & 0.39 & 0.04 & Protection (83) \\
\hline IL-6 & Brazilian & (GG) rs2069845 & ENL & NR & 1.92 & 0.04 & Susceptibility (83) \\
\hline IL-6 & Brazilian & $(G G+A G) r s 2069845$ & ENL & NR & 2.59 & 0.045 & Susceptibility (83) \\
\hline IL-12B & Indian & 3'UTR2.2 & Leprosy & Controls & - & 0.001 & Protection (85) \\
\hline IL-12 & Mexican & 3'UTR 1188 A/C (CC) & LL & Controls & - & $<0.05$ & Susceptibility (86) \\
\hline IL-12 & Mexican & 3'UTR 1188 AVC (AC) & LL & Controls & - & $<0.05$ & Protection (86) \\
\hline IL12B & Chinese & rs6871626 & Leprosy & Controls & 0.75 & $3.95 \times 10^{18}$ & Protection (88) \\
\hline IL18RAP & Chinese & rs2058660 & Leprosy & Controls & 1.30 & $4.57 \times 10^{19}$ & Susceptibility (88) \\
\hline IL12B & Indian & (AA vs. AC + CC) rs2853694 & Leprosy & Controls & 1.42 & $2.6 \times 10^{4}$ & Susceptibility (89) \\
\hline IL-10 & Brazilian & $819 \mathrm{~T}$ & Leprosy & Controls & 1.35 & 0.03 & Susceptibility (91) \\
\hline IL-10 & Brazilian & $819 \pi$ & Leprosy & Controls & 2.64 & 0.04 & Susceptibility (69) \\
\hline IL-10 & Brazilian & 819T & PB & $\mathrm{MB}$ & 2.28 & 0.01 & Susceptibility (69) \\
\hline IL-10 & Colombian & (C/C and C/T) rs1800871 & Leprosy & Controls & 4.34 & $<0.001$ & Susceptibility (92) \\
\hline IL-10 & Colombian & $(\mathrm{C} / \mathrm{C}$ and $\mathrm{C} / \mathrm{A}) \mathrm{rs} 1800872$ & Leprosy & Controls & 4.3 & $<0.001$ & Susceptibility (92) \\
\hline$I L-10$ & Colombian & Haplotype (819C-519C) & Leprosy & Controls & 4.34 & $<0.001$ & Susceptibility (92) \\
\hline IL-10 & Colombian & 1082A-819C-592C & Leprosy & Controls & 6.25 & $<0.001$ & Susceptibility (92) \\
\hline IL-10 & Brazilian & $-3575-2849-2763$ & Leprosy & Controls & - & 0.044 & Susceptibility (93) \\
\hline $1 L-10$ & Brazilian & $-3575 A-2849 G-2763 C$ & Leprosy & Controls & 0.35 & 0.005 & Protection (93) \\
\hline IL-10 & Indian & -819 (TT vs. CT + CC) & Leprosy & Controls & 2.50 & $<0.005$ & Susceptibility (94) \\
\hline IL-10 & Indian & -819 (CC vs. CT + TT) & Leprosy & Controls & 0.59 & 0.005 & Protection (94) \\
\hline IL-10 & Indian & $-592(\mathrm{AA}$ vs. $\mathrm{CA}+\mathrm{CC})$ & Leprosy & Controls & 2.43 & $<0.005$ & Susceptibility (94) \\
\hline $\operatorname{LL}-10$ & Indian & $-592(C C$ vs. $C A+A A)$ & Leprosy & Controls & 0.60 & 0.006 & Protection (94) \\
\hline$I L-10$ & Indian & -3575T-2849G-2763C-1082A-819C-592C & Leprosy & Controls & 0.58 & 0.01 & Protection (94) \\
\hline$I L-10$ & Brazilian & $1082 G-819 C-592 C$ & $\mathrm{LL}$ & Controls & - & 0.02 & Protection (70) \\
\hline
\end{tabular}

MB, multibacillary; PB, paucibacillary; BB, mid-borderline; BL, borderline lepromatous; BB, borderline tuberculoid; $L L$, lepromatous leprosy; $T T$, tuberculoid leprosy; per se, leprosy independent of specific clinical manifestations; ENL, type 2 reactions or erythema nodosum leprosum; RR, type I or reversal reaction; NR, leprosy who did not have reaction; UTR, untranslated region; OR, odds ratio; rr, relative risk; P values; SNPs, single-nucleotide polymorphisms.

the association between the CD14 -159C/T polymorphism and tuberculosis (88 patients vs. 116 control subjects) was investigated. There was no significant difference in terms of genotype distribution between patients with tuberculosis and controls, but serum levels of sCD14 were significantly increased in patients with active tuberculosis compared to those with inactive tuberculosis and healthy controls $(P<0.001)(104)$.

The most of associations of innate immune response genes and leprosy are summarized in Tables 1-4.

\section{CONCLUSION}

The studies discussed in this review were conducted in diverse populations where the incidence of the disease is still high. Although the results are consistent with the biological functions of their polymorphic genes, many studies present a number of samples down to be regarded as true and consistent science. This would need from the data shown in the literature, a continuation of research aimed at understanding the mechanisms of infection and defense to $M$. leprae with larger number of samples and selected controls (household contacts), and later of great relevance, replication of the main findings in other populations the incidence of the disease remains high, giving continuation to the transmission chain.
It will be a great advance to define in the near future, the exact polymorphisms that lead to the clinical outcome of leprosy, and that make individuals possessing up of resistant form to infection or even spontaneous healing. Most findings are also presented in a simplified manner without further deepening the understanding of the disease outcome, only indicating a possible influence in leprosy, so parking not completing a broader range with concrete explanations and proven based on studies standards case-control, statistical rules, the local incidence of the disease investigated and can sometimes generate false positives, slowing the scientific understanding of the disease.

\section{FUTURE PERSPECTIVES}

Whereas the intervention model for disease control is based on early diagnosis, timely treatment of all diagnosed cases, prevention and treatment of disabilities and surveillance of household contacts; genetic characterization of gene polymorphisms of the immune response of a population that developed leprosy, will investigate the influence of these genes in the resistance or susceptibility to disease and lor clinical forms, and can generate a characteristic genetic profile of patients and controls in this way we can redirect drug therapy according to the individual's profile. 
This step may be essential to prevent the development of leprosy reactions, because the patient be diagnosed as early as possible and with the most appropriate medication their clinical form. Another advantage of the characterization of genetic patient profile will be compared to their close contacts, so we can see very clearly where there was immunological failure, and the profiles are similar, you can investigate the replacement of the drugs used in order to avoid the development of leprosy in individuals with susceptible profiles. Thus, studies are needed with genes and their receptors from the recognition of the microorganism to the outcome of the disease to determine the involvement of these genes in the immunopathogenesis of leprosy patients and not consanguineous individuals who live together next.

\section{REFERENCES}

1. Fitness J, Tosh K, Hill AVS. Genetics of susceptibility to leprosy. Genes Immun (2002) 3(8):441-53. doi:10.1038/sj.gene.6363926

2. Walker S, Lockwood D. Leprosy. Clin Dermatol (2007) 25:165-72. doi:10.1016/j.clindermatol.2006.05.012

3. Ridley DS. Classification of leprosy according to immunity. A five-group system. Int J Lepr (1966) 34:255-73.

4. Alter A, Alcais A, Abel L, Schurr E. Leprosy as a genetic model for susceptibility to common infectious diseases. Hum Genet (2008) 123(3):227-35. doi:10.1007/s00439-008-0474-z

5. Francheschi DSA, Sacramento WSD, Mazini PS, Visentainer JEL. Hanseníase no Mundo Moderno: O Que Sabemos Sobre a Influência Genética do Hospedeiro no seu Controle? Arq Med (2009) 23:159-65.

6. Modlin RL. The innate immune response in leprosy. Curr Opin Immunol (2010) 22(1):48-51. doi:10.1016/j.coi.2009.12.001

7. Moraes MO, Cardoso CC, Vanderborght PR, Pacheco AG. Genetics of host response in leprosy. Lepr Rev (2006) 77(3):189-202.

8. Prevedello FC, Mira MT. Hanseníase: una doenca genetica? Leprosy: a genetic disease. An Bras Dermatol (2007) 82:451-9. doi:10.1590/ S0365-05962007000500009

9. Malhotra D, Relhan V, Reddy BS, Bamezai R. TLR2 Arg677Trp polymorphism in leprosy: revisited. Hum Genet (2005) 116(5):413-5. doi:10.1007/ s00439-004-1249-9

10. Johnson JCM, Lyle EA, Omueti KO, Stepensky VA, Yegin O, Alpsoy E, et al. Cutting edge: a common polymorphism impairs cell surface trafficking and functional responses of TLR1 but protects against leprosy. J Immunol (2007) 178(12):7520-4. doi:10.4049/jimmunol.178.12.7520

11. Brightbill HD, Libraty DH, Krutzik SR, Yang RB, Belisle JT, Bleharski JR, et al. Host defense mechanisms triggered by microbial lipoproteins through toll-like receptors. Science (1999) 285(5428):732-6. doi:10.1126/ science.285.5428.732

12. Krutzik SR, Ochoa MT, Sieling PA, Uematsu S, Ng YW, Legaspi A, et al. Activation and regulation of toll-like receptors 2 and 1 in human leprosy. Nat Med (2003) 9(5):525-32. doi:10.1038/nm864

13. Bekker LG, Freeman S, Murray PJ, Ryffel B, Kaplan G. TNF-alpha controls intracellular mycobacterial growth by both inducible nitric oxide synthase-dependent and inducible nitric oxide synthase-independent pathways. J Immunol (2001) 166(11):6728-34. doi:10.4049/jimmunol.166.11.6728

14. Kawai T, Akira S. The roles of TLRs, RLRs and NLRs in pathogen recognition. Int Immunol (2009) 21(4):317-37. doi:10.1093/intimm/dxp017

15. Schuring RP, Hamann L, Faber WR, Pahan D, Richardus JH, Schumann $\mathrm{RR}$, et al. Polymorphism N248S in the human Toll-like receptor 1 gene is related to leprosy and leprosy reactions. J Infect Dis (2009) 199(12):1816-9. doi:10.1086/599121

16. Marques Cde S, Brito-de-Souza VN, Guerreiro LT, Martins JH, Amaral EP, Cardoso CC, et al. Toll-like receptor 1 N248S single-nucleotide polymorphism is associated with leprosy risk and regulates immune activation during

\section{ACKNOWLEDGMENTS}

The authors thank Tania Mara de Oliveira who revised linguistically this manuscript.

\section{FUNDING}

Funded by the University of Coimbra, Portugal and FEDER (Fundo Europeu de Desenvolvimento Regional) through COMPETE (Programa Operacional Factores de Competitividade) and FCT (Fundação para a Ciência e Tecnologia) through project PEst-C/SAU/LA0001/2013-2014.

mycobacterial infection. J Infect Dis (2013) 208(1):120-9. doi:10.1093/infdis/ jit133

17. Wong SH, Gochhait S, Malhotra D, Pettersson FH, Teo YY, Khor CC, et al. Leprosy and the adaptation of human toll-like receptor 1. PLoS Pathog (2010) 6:e1000979. doi:10.1371/journal.ppat.1000979

18. Randhawa AK, Shey MS, Keyser A, Peixoto B, Wells RD, de Kock M, et al. Association of human TLR1 and TLR6 deficiency with altered immune responses to BCG vaccination in South African infants. PLoS Pathog (2011) 7:e1002174. doi:10.1371/journal.ppat.1002174

19. Bochud PY, Hawn TR, Siddiqui MR, Saunderson P, Britton S, Abraham I, et al. Toll-like receptor 2 (TLR2) polymorphisms are associated with reversal reaction in leprosy. J Infect Dis (2008) 197(2):253-61. doi:10.1086/524688

20. Suryadevara NC, Neela VS, Devalraju KP, Jain S, SivaSai KS, Valluri VL, et al. Influence of Intron II microsatellite polymorphism in human toll-like receptor 2 gene in leprosy. Hum Immunol (2013) 74(8):1034-40. doi:10.1016/j. humimm.2013.04.009

21. Bochud PY, Sinsimer D, Aderem A, Siddiqui MR, Saunderson P, Britton S, et al. Polymorphisms in toll-like receptor 4 (TLR4) are associated with protection against leprosy. Eur J Clin Microbiol Infect Dis (2009) 28(9):1055-65. doi:10.1007/s10096-009-0746-0

22. Goulart LR, Ferreira FR, Goulart IM. Interaction of TaqI polymorphism at exon 9 of the vitamin $\mathrm{D}$ receptor gene with the negative lepromin response may favor the occurrence of leprosy. FEMS Immunol Med Microbiol (2006) 48(1):91-8. doi:10.1111/j.1574-695X.2006.00128.x

23. Roy S, Frodsham A, Saha B, Hazra SK, Mascie-Taylor CG, Hill AV. Association of vitamin D receptor genotype with leprosy type. J Infect Dis (1999) 179(1):187-91. doi:10.1086/314536

24. Mora JR, Iwata M, von Andrian UH. Vitamin effects on the immune system: vitamins A and D take centre stage. Nat Rev Immunol (2008) 8(9):658-98. doi: $10.1038 /$ nri2378

25. Sapkota BR, Macdonald M, Berrington WR, Misch EA, Ranjit C, Siddiqui $\mathrm{MR}$, et al. Association of TNF, MBL, and VDR polymorphisms with leprosy phenotypes. Hum Immunol (2010) 71(10):992-8. doi:10.1016/j. humimm.2010.07.001

26. Felix JSV, Salazar SGC, Velazquez RC, Maldonado JGR, Villalobos HR. Association between the TaqI polymorphism of the vitamin $\mathrm{D}$ receptor gene and lepromatous leprosy in a Mexican population sample. Salud Publica Mex (2009) 51(1):59-61.

27. Fitness J, Floyd S, Warndorff DK, Sichali L, Mwaungulu L, Crampin AC, et al. Large-scale candidate gene study of leprosy susceptibility in the Karonga district of Northern Malawi. Am J Trop Med Hyg (2004) 71(3):330-40.

28. Skamene E, Gros P, Forget A, Kongshavn PAL, St Charles C, Taylor BA. Genetic regulation of resistance to intracellular pathogens. Nature (1982) 297(5866):506-9. doi:10.1038/297506a0

29. Ferreira FR, Goulart LR, Silva HD, Goulart IM. Susceptibility to leprosy may be conditioned by an interaction between the NRAMP1 promoter polymorphisms and the lepromin response. Int J Lepr Other Mycobact Dis (2004) 72(4):457-567. doi:10.1489/1544-581X(2004)72<457:STLMBC>2.0.CO;2 
30. Alcaïs A, Sanchez FO, Thuc NV, Lap VD, Oberti J, Lagrange PH, et al. Granulomatous reaction to intradermal injection of lepromin (Mitsuda reaction) is linked to the human NRAMP1 gene in Vietnamese leprosy sibships. J Infect Dis (2000) 181(1):302-8. doi:10.1086/315174

31. Hatta M, Ratnawati, Tanaka M, Ito J, Shirakawa T, Kawabata M. NRAMP1/ SLC11A1 gene polymorphisms and host susceptibility to Mycobacterium tuberculosis and M. leprae in South Sulawesi, Indonesia. Southeast Asian J Trop Med Public Health (2010) 41(2):386-94.

32. Meisner SJ, Mucklow S, Warner G, Sow SO, Lienhardt C, Hill AV. Association of NRAMP1 polymorphism with leprosy type but not susceptibility to leprosy per se in West Africans. Am J Trop Med Hyg (2001) 65(6):733-5.

33. Vejbaesya S, Mahaisavariya P, Luangtrakool P, Sermduangprateep C. TNF alpha and NRAMP1 polymorphisms in leprosy. J Med Assoc Thai (2007) 90(6):1188-92.

34. Roger M, Levee G, Chanteau S, Gicquel B, Schurr E. No evidence for linkage between leprosy susceptibility and the human natural resistance-associated macrophage protein 1 (NRAMP1) gene in French Polynesia. Int J Lepr Other Mycobact Dis (1997) 65(2):197-202.

35. Teixeira MA, Silva NL, Ramos Ade L, Hatagima A, Magalhães V. NRAMP1 gene polymorphisms in individuals with leprosy reactions attended at two reference centers in Recife, northeastern Brazil. Rev Soc Bras Med Trop (2010) 43(3):281-6.

36. Abel L, Sánchez FO, Oberti J, Thuc NV, Hoa LV, Lap VD, et al. Susceptibility to leprosy is linked to the human NRAMP1 gene. J Infect Dis (1998) 177(1):133-45. doi:10.1086/513830

37. Alter A, de Léséleuc L, Van Thuc N, Thai VH, Huong NT, Ba NN, et al. Genetic and functional analysis of common MRC1 exon 7 polymorphisms in leprosy susceptibility. Hum Genet (2010) 127(3):337-48. doi:10.1007/ s00439-009-0775-x

38. Wang D, Feng JQ, Li YY, Zhang DF, Li XA, Li QW, et al. Genetic variants of the $\mathrm{MRC1}$ gene and the IFNG gene are associated with leprosy in Han Chinese from Southwest China. Hum Genet (2012) 131(7):1251-60. doi:10.1007/ s00439-012-1153-7

39. Torrado E, Cooper AM. IL-17 and Th17 cells in tuberculosis. Cytokine Growth Factor Rev (2010) 21(6):455-62. doi:10.1016/j.cytogfr.2010.10.004

40. Zhang FR, Huang W, Chen SM, Sun LD, Liu H, Li Y, et al. Genomewide association study of leprosy. N Engl J Med (2009) 361(27):2609-18. doi:10.1056/ NEJMoa0903753

41. Marcinek P, Jha AN, Shinde V, Sundaramoorthy A, Rajkumar R, Suryadevara NC, et al. LRRK2 and RIPK2 variants in the NOD 2-mediated signaling pathway are associated with susceptibility to Mycobacterium leprae in Indian populations. PLoS One (2013) 8(8):e73103. doi:10.1371/journal.pone.0073103

42. Pan H, Dai Y, Tang S, Wang J. Polymorphisms of NOD2 and the risk of tuberculosis: a validation study in the Chinese population. Int J Immunogenet (2012) 39(3):233-40. doi:10.1111/j.1744-313X.2011.01079.x

43. Grant AV, Alter A, Huong NT, et al. Crohn's disease susceptibility genes are associated with leprosy in the Vietnamese population. J Infect Dis (2012) 206(11):1763-7. doi:10.1093/infdis/jis588

44. Sales-Marques C, Salomão H, Fava VM, Alvarado-Arnez LE, Amaral EP, Cardoso CC, et al. NOD2 and CCDC122-LACC1 genes are associated with leprosy susceptibility in Brazilians. Hum Genet (2014) 133(12):1525-32. doi:10.1007/s00439-014-1502-9

45. Berrington WR, Macdonald M, Khadge S, Sapkota BR, Janer M, Hagge DA, et al. Common polymorphisms in the NOD2 gene region are associated with leprosy and its reactive states. J Infect Dis (2010) 201(9):1422-35. doi:10.1086/651559

46. Singh V, Gaur R, Mittal M, Biswas SK, Das R, Girdhar BK, et al. Absence of nucleotide-binding oligomerization domain-containing protein 2 variants in patients with leprosy and tuberculosis. Int J Immunogenet (2012) 39(4):353-6. doi:10.1111/j.1744-313X.2012.01085.x

47. Ferwerda G, Girardin SE, Kullberg BJ, Le Bourhis L, de Jong DJ, Langenberg $\mathrm{DM}$, et al. NOD2 and toll-like receptors are nonredundant recognition systems of Mycobacterium tuberculosis. PLoS Pathog (2005) 1(3):279-85. doi:10.1371/journal.ppat.0010034

48. Austin CM, Ma X, Graviss EA. Common nonsynonymous polymorphisms in the NOD2 gene are associated with resistance or susceptibility to tuberculosis disease in African Americans. J Infect Dis (2008) 197(12):1713-6. doi:10.1086/588384
49. Vasconcelos LR, Fonseca JP, do Carmo RF, de Mendonça TF, Pereira VR, Lucena-Silva N, et al. Mannose-binding lectin serum levels in patients with leprosy are influenced by age and MBL2 genotypes. Int J Infect Dis (2011) 15(8):551-7. doi:10.1016/j.ijid.2011.04.008

50. Zhang DF, Huang XQ, Wang D, Li YY, Yao YG. Genetic variants of complement genes ficolin-2, mannose-binding lectin and complement factor $\mathrm{H}$ are associated with leprosy in Han Chinese from Southwest China. Hum Genet (2013) 132(6):629-40. doi:10.1007/s00439-013-1273-8

51. de Messias-Reason IJ, Boldt AB, Moraes Braga AC, Stahlke EVRS, Dornelles L, Pereira-Ferrari L, et al. The association between mannan-binding lectin gene polymorphism and clinical leprosy: new insight into an old paradigm. $J$ Infect Dis (2007) 196(9):1379-85. doi:10.1086/521627

52. West AB, Lockhart PJ, O'Farell C, Farrer MJ. Identification of a novel gene linked to parkin via a bi-directional promoter. J Mol Biol (2003) 326(1):11-9. doi:10.1016/S0022-2836(02)01376-1

53. Mira MT, Alcais A, Nguyen VT, et al. Susceptibility to leprosy is associated with PARK2 and PACRG. Nature (2004) 427(6975):636-40. doi:10.1038/ nature 02326

54. Alter A, Fava VM, Huong NT, Singh M, Orlova M, Van Thuc N, et al. Linkage disequilibrium pattern and age-at-diagnosis are critical for replicating genetic associations across ethnic groups in leprosy. Hum Genet (2013) 132(1):107-16. doi:10.1007/s00439-012-1227-6

55. Li J, Liu H, Liu J, et al. Association study of the single nucleotide polymorphisms of PARK2 and PACRG with leprosy susceptibility in Chinese population. Eur J Hum Genet (2012) 20(5):488-9. doi:10.1038/ejhg.2011.190

56. Malhotra D, Darvishi K, Lohra M, Kumar H, Grover C, Sood S, et al. Association study of major risk single nucleotide polymorphisms in the common regulatory region of PARK2 and PACRG genes with leprosy in an Indian population. Eur J Hum Genet (2006) 14(4):438-42. doi:10.1038/ sj.ejhg. 5201563

57. Chopra R, Ali S, Srivastava AK, Aggarwal S, Kumar B, Manvati S, et al. Mapping of PARK2 and PACRG overlapping regulatory region reveals LD structure and functional variants in association with leprosy in unrelated Indian population groups. PLoS Genet (2013) 9(7):e1003578. doi:10.1371/ journal.pgen.1003578

58. Tosh K, Ravikumar M, Bell JT, Meisner S, Hill AV, Pitchappan R. Variation in MICA and MICB genes and enhanced susceptibility to paucibacillary leprosy in South India. Hum Mol Genet (2006) 15(19):2880-7. doi:10.1093/ $\mathrm{hmg} / \mathrm{ddl} 229$

59. Ribas F, Oliveira LA, Petzl-Erler ML, Bicalho MG. Major histocompatibility complex class I chain-related gene A polymorphism and linkage disequilibrium with HLA-B alleles in Euro-Brazilians. Tissue Antigens (2008) 72(6):532-8. doi:10.1111/j.1399-0039.2008.01142.x

60. Wang LM, Kimura A, Satoh M, Mineshita S. HLA linked with leprosy in Southern China; HLA-Linked resistance alleles to leprosy. Int J Lepr Other Mycobact Dis (1999) 67(4):403-8.

61. Mizuki N, Ota M, Kimura M, et al. Triplet repeat polymorphism in the transmembrane region of the MICA gene: a strong association of six GCT repetitions with Behcet disease,. Proc Natl Acad Sci U S A (1997) 94(4):1298-303. doi:10.1073/pnas.94.4.1298

62. do Sacramento WS, Mazini PS, Franceschi DA, de Melo FC, Braga MA, Sell AM, et al. Frequencies of MICA alleles in patients from southern Brazil with multibacillary and paucibacillary leprosy. Int J Immunogenet (2012) 39(3):210-5. doi:10.1111/j.1744-313X.2011.01074.x

63. Robinson J, Mistry K, McWilliam H, Lopez R, Marsh SGE. IPD - the immuno polymorphism database. Nucleic Acids Res (2010) 38:D863-9. doi:10.1093/ nar/gkp879

64. Parham P. Killer cell immunoglobulin-like receptor diversity: balancing signals in the natural killer cell response. Immunol Lett (2004) 92(1-2):11-3. doi:10.1016/j.imlet.2003.11.016

65. Franceschi DS, Mazini PS, Rudnick CC, Sell AM, Tsuneto LT, de Melo FC, et al. Association between killer-cell immunoglobulin-like receptor genotypes and leprosy in Brazil. Tissue Antigens (2008) 72(5):478-82. doi:10.1111/j.1399-0039.2008.01127.x

66. Jarduli LR, Alves HV, de Souza-Santana FC, et al. Influence of KIR genes and their HLA ligands in the pathogenesis of leprosy in a hyperendemic population of rondonopolis, southern Brazil. BMC Infect Dis (2014) 14:438. doi:10.1186/1471-2334-14-438 
67. Santos AR, Almeida AS, Suffys PN, Moraes MO, Filho VF, Mattos HJ, et al. Tumor necrosis factor promoter polymorphism (TNF2) seems to protect against development of severe forms of leprosy in a pilot study in Brazilian patients. Int J Lepr Other Mycobact Dis (2000) 68(3):325-7.

68. Shaw MA, Donaldson IJ, Collins A, et al. Association and linkage of leprosy phenotypes with HLA class II and tumour necrosis factor genes. Genes Immun (2001) 2(4):196-204. doi:10.1038/sj.gene.6363754

69. Santos AR, Suffys PN, Vanderborght PR, Moraes MO, Vieira LM, Cabello $\mathrm{PH}$, et al. Role of tumor necrosis factor-alpha and interleukin-10 promoter gene polymorphisms in leprosy. J Infect Dis (2002) 186(11):1687-91. doi:10.1086/345366

70. Franceschi DS, Mazini PS, Rudnick CC, Sell AM, Tsuneto LT, Ribas ML, et al. Influence of TNF and IL10 gene polymorphisms in the immunopathogenesis of leprosy in the south of Brazil. Int J Infect Dis (2009) 13(4):493-598. doi:10.1016/j.ijid.2008.08.019

71. Moraes MO, Duppre NC, Suffys PN, et al. Tumor necrosis factor-alpha promoter polymorphism TNF2 is associated with a stronger delayedtype hypersensitivity reaction in the skin of borderline tuberculoid leprosy patients. Immunogenetics (2001) 53(1):45-7. doi:10.1007/ s002510000295

72. Cardoso CC, Pereira AC, Brito-de-Souza VN, et al. TNF-308G> A single nucleotide polymorphism is associated with leprosy among Brazilians: a genetic epidemiology assessment, meta-analysis, and functional study. $J$ Infect Dis (2011) 204(8):1256-63. doi:10.1093/infdis/jir521

73. Vanderborght PR, Matos HJ, Salles AM, Vasconcellos SE, Silva-Filho VF, Huizinga TW, et al. Single nucleotide polymorphisms (SNPs) at -238 and -308 positions in the TNFalpha promoter: clinical and bacteriological evaluation in leprosy. Int J Lepr Other Mycobact Dis (2004) 72(2):143-8. doi:10.14 89/1544-581X(2004)072<0143:SNPSAA > 2.0.CO;2

74. Félix JSV, Cázarez-Salazar S, Ríos-Tostado JJ, Flores-Garcia A, RangelVillalobos H, Murillo-Llanes J. Lack of effects of the TNF-a and IL-10 gene polymorphisms in Mexican patients with lepromatous leprosy. Lepr Rev (2012) 83(1):34-9.

75. Moraes MO, Sarno EN, Almeida AS, Saraiva BC, Nery JA, Martins RC, et al. Cytokine mRNA expression in leprosy: a possible role for interferon-gamma and interleukin-12 in reactions (RR and ENL). Scand J Immunol (1999) 50(5):541-9. doi:10.1046/j.1365-3083.1999.00622.x

76. Levee G, Schurr E, Pandey JP. Tumor necrosis factor-alpha, interleukin-1-beta and immunoglobulin (GM and KM) polymorphisms in leprosy. A linkage study. Exp Clin Immunogenet (1997) 14(2):160-5.

77. Ali S, Chopra R, Aggarwal S, Srivastava AK, Kalaiarasan P, Malhotra D, et al. Association of variants in BAT1-LTA-TNF-BTNL2 genes within 6p21.3 region show graded risk to leprosy in unrelated cohorts of Indian population. Hum Genet (2012) 131(5):703-16. doi:10.1007/s00439-011-1114-6

78. Allcock RJN, Williams JH, Price P. The central MHC gene, BAT1, may encode a protein that down-regulates cytokine production. Genes Cells (2001) 6(5):487-94. doi:10.1046/j.1365-2443.2001.00435.x

79. Cardoso CC, Pereira AC, Brito-de-Souza VN, et al. IFNG +874 T > A single nucleotide polymorphism is associated with leprosy among Brazilians. Hum Genet (2010) 128(5):481-90. doi:10.1007/s00439-010-0872-x

80. Silva GAV, Santos MP, Mota-Passos I, et al. IFN-gamma +875 microsatellite polymorphism as a potential protection marker for leprosy patients from Amazonas state, Brazil. Cytokine (2012) 60(2):493-7. doi:10.1016/j. cyto.2012.04.043

81. Reynard MP, Turner D, Junqueira-Kipnis AP, Ramos de Souza M, Moreno C, Navarrete CV. Allele frequencies for an interferon-gamma microsatellite in a population of Brazilian leprosy patients. Eur J Immunogenet (2003) 30(2):149-51. doi:10.1046/j.1365-2370.2003.00377.x

82. Matsuda T, Hirano T. Interleukin 6 (IL-6). Biotherapy (1990) 2(4):363-73. doi:10.1007/BF02170085

83. Sousa AL, Fava VM, Sampaio LH, Martelli CM, Costa MB, Mira MT, et al. Genetic and immunological evidence implicates interleukin 6 as a susceptibility gene for leprosy type 2 reaction. J Infect Dis (2012) 205(9):1417-24. doi:10.1093/infdis/jis208

84. Lotze MT, Shurin MR, Esche C, Tahara H, Storkus W, Kirkwood JM, et al. Interleukin-2: developing additional cytokine gene therapies using fibroblasts or dendritic cells to enhance tumor immunity. Cancer J Sci Am (2000) (Suppl 1):S61-6.
85. Morahan G, Kaur G, Singh M, Rapthap CC, Kumar N, Katoch K, et al. Association of variants in the IL12B gene with leprosy and tuberculosis. Tissue Antigens (2007) 69:234-6. doi:10.1111/j.1399-0039.2006.773_3.x

86. Alvarado-Navarro A, Montoya-Buelna M, Muñoz-Valle JF, López-Roa RI, Guillén-Vargas C, Fafutis-Morris M. The 3' UTR 1188 A/C polymorphism in the interleukin-12p40 gene (IL-12B) is associated with lepromatous leprosy in the west of Mexico. Immunol Lett (2008) 118(2):148-51. doi:10.1016/j. imlet.2008.03.015

87. Jesus Salvador VF, Jose Guadalupe RM, Luis Antonio OR, Hector RV. "Lack of association between 3' UTR 1188 A/C polymorphism in the IL-12p40 gene and lepromatous leprosy in Sinaloa, Mexico. Int J Dermatol (2012) 51(7):875-6. doi:10.1111/j.1365-4632.2010.04597.x

88. Liu H, Irwanto A, Tian HQ, Fu X, Yu Y, Yu G, et al. Identification of IL18RAP/ IL18R1 and IL12B as leprosy risk genes demonstrates shared pathogenesis between inflammation and infectious diseases. Am J Hum Genet (2012) 91(5):935-41. doi:10.1016/j.ajhg.2012.09.010

89. Ali S, Srivastava AK, Chopra R, Aggarwal S, Garg VK, Bhattacharya SN, et al. IL12B SNPs and copy number variation in IL23R gene associated with susceptibility to leprosy. J Med Genet (2013) 50(1):34-42. doi:10.1136/ jmedgenet-2012-101214

90. Malefyt RW. IL-10. In Cytokine Reference: A Compendium of Cytokines and Other Mediators of Host Defense, Academic Press (2000). p. 165-85.

91. Pereira AC, Brito-de-Souza VN, Cardoso CC, Dias-Baptista IM, Parelli FP, Venturini J, et al. Genetic, epidemiological and biological analysis of interleukin-10 promoter single-nucleotide polymorphisms suggests a definitive role for $-819 \mathrm{C} / \mathrm{T}$ in leprosy susceptibility. Genes Immun (2009) 10(2):174-80. doi:10.1038/gene.2008.97

92. Cardona-Castro N, Sanchez-Jimenez M, Rojas W, Bedoya-Berrio G. IL-10 gene promoter polymorphisms and leprosy in a Colombian population sample. Biomedica (2012) 32(1):71-6. doi:10.1590/ S0120-41572012000100009

93. Moraes MO, Pacheco AG, Schonkeren JJ, Vanderborght PR, Nery JA, Santos $\mathrm{AR}$, et al. Interleukin-10 promoter single-nucleotide polymorphisms as markers for disease susceptibility and disease severity in leprosy. Genes Immun (2004) 5(7):592-5. doi:10.1038/sj.gene.6364122

94. Malhotra D, Darvishi K, Sood S, Sharma S, Grover C, Relhan V, et al. IL10 promoter single nucleotide polymorphisms are significantly associated with resistance to leprosy. Hum Genet (2005) 118(2):295-300. doi:10.1007/ s00439-005-0042-8

95. Pacheco E, Fonseca C, Montes C, Zabaleta J, Garcia LF, Arias MA. CD14 gene promoter polymorphism in different clinical forms of tuberculosis. FEMS Immunol Med Microbiol (2004) 40(3):207-13. doi:10.1016/ S0928-8244(03)00369-9

96. Burgmann H, Winkler S, Locker GJ, Presterl E, Laczika K, Staudinger T, et al. Increased serum concentration of soluble CD14 is a prognostic marker in Gram-positive sepsis. Clin Immunol Immunopathol (1996) 80:307-10. doi:10.1006/clin.1996.0128

97. Kagan JC, Medzhitov R. Phosphoinositide-mediated adaptor recruitment controls Toll-like receptor signaling. Cell (2006) 125(5):943-55. doi:10.1016/j. cell.2006.03.047

98. Kagan JC, Su T, Horng T, Chow A, Akira S, Medzhitov R. TRAM couples endocytosis of Toll-like receptor 4 to the induction of interferon-beta. Nat Immunol (2008) 9(4):361-8. doi:10.1038/ni1569

99. Tarassishin L, Suh HS, Lee SC. LPS and IL-1 differentially activate mouse and human astrocytes: role of CD14. Glia (2014) 62(6):999-1013. doi:10.1002/ glia.22657

100. Druszczyńska M, Strapagiel D, Kwiatkowska S, Kowalewicz-Kulbat M, Rózalska B, Chmiela M, et al. Tuberculosis bacilli still posing a threat. Polymorphism of genes regulating anti-mycobacterial properties of macrophages. Pol J Microbiol (2006) 55(1):7-12.

101. Kang YA, Lee HW, Kim YW, Han SK, Shim YS, Yim JJ. Association between the $-159 \mathrm{C} / \mathrm{T}$ CD14 gene polymorphism and tuberculosis in a Korean population. FEMS Immunol Med Microbiol (2009) 57(3):229-35. doi:10.1111/j.1574-695X.2009.00602.x

102. Zhao MY, Xue Y, Zhao ZQ, Li FJ, Fan DP, Wei LL, et al. Association of CD14 G(-1145)A and C(-159)T polymorphisms with reduced risk for tuberculosis in a Chinese Han population. Genet Mol Res (2012) 11(3):3425-31. doi:10.4238/2012.September.25.11 
103. Xue Y, Zhao ZQ, Chen F, Zhang L, Li GD, Ma KW, et al. Polymorphisms in the promoter of the CD14 gene and their associations with susceptibility to pulmonary tuberculosis. Tissue Antigens (2012) 80(5):437-43. doi:10.1111/j.1399-0039.2012.01958.x

104. Ayaslioglu E, Kalpaklioglu F, Kavut AB, Erturk A, Capan N, Birben E. The role of CD14 gene promoter polymorphism in tuberculosis susceptibility. J Microbiol Immunol Infect (2013) 46(3):158-63. doi:10.1016/j. jmii.2012.05.008

105. Miao R, Ge H, Xu L, Xu F. CD14 -159C/T polymorphism contributes to the susceptibility to tuberculosis: evidence from pooled 1,700 cases and 1,816 controls. Mol Biol Rep (2014) 41(5):3481-6. doi:10.1007/s11033-014-3210-x

106. Rosas-Taraco AG, Revol A, Salinas-Carmona MC, Rendon A, CaballeroOlin G, Arce-Mendoza AY. CD14 C(-159)T polymorphism is a risk factor for development of pulmonary tuberculosis. J Infect Dis (2007) 196(11):1698706. doi:10.1086/522147

107. Vercelli D, Baldini M, Stern D, Lohman IC, Halonen M, Martinez F. CD14: a bridge between innate immunity and adaptive IgE responses. J Endotoxin Res (2001) 7(1):45-8. doi:10.1179/096805101101532521
108. Liang XH, Cheung W, Heng CK, Liu JJ, Li CW, Lim B, et al. "CD14 promoter polymorphisms have no functional significance and are not associated with atopic phenotypes. Pharmacogenet Genomics (2006) 16(4):229-36. doi:10.1097/01.fpc.0000197466.14340.0f

109. Guo Q, Zhu J, Xia B. Polymorphism of CD14 gene but not the mutation of TLR4 gene is associated with colorectal cancer in Chinese patients. J Gastroenterol Hepatol (2006) 21:92-7. doi:10.1111/j.1440-1746.2005.04156.x

Conflict of Interest Statement: The author declares that the research was conducted in the absence of any commercial or financial relationships that could be construed as a potential conflict of interest.

Copyright (C) 2016 Mazini, Alves, Reis, Lopes, Sell, Santos-Rosa, Visentainer and Rodrigues-Santos. This is an open-access article distributed under the terms of the Creative Commons Attribution License (CC BY). The use, distribution or reproduction in other forums is permitted, provided the original author(s) or licensor are credited and that the original publication in this journal is cited, in accordance with accepted academic practice. No use, distribution or reproduction is permitted which does not comply with these terms. 